University of New Haven

University of

New Haven

Digital Commons@ New Haven

$3-2017$

Life Cycle Environmental and Economic Performance of Biochar Compared with Activated Carbon: A Meta-Analysis

Hashim A. Alhashimi

University of New Haven

Can B. Aktas

University of New Haven, caktas@newhaven.edu

Follow this and additional works at: http://digitalcommons.newhaven.edu/civilengineering-facpubs Part of the Civil Engineering Commons

\title{
Publisher Citation
}

Alhashimi, H. A., \& Aktas, C. B. (2017). Life cycle environmental and economic performance of biochar compared with activated carbon: A meta-analysis. Resources, Conservation and Recycling, 118, 13-26.

Comments

This is the authors' accepted version of the article published in https://doi.org/10.1016/j.resconrec.2016.11.016 


\section{Life Cycle Environmental and Economic Performance of Biochar Compared with}

2 Activated Carbon: A Meta-Analysis

3 Hashim A. Alhashimi ${ }^{\mathrm{a}}$, Can B. Aktas ${ }^{\S, \mathrm{a}}$

4

$5 \quad \S$ Corresponding author email: caktas@newhaven.edu

$6{ }^{\mathrm{a}}$ Department of Civil and Environmental Engineering, University of New Haven, West Haven, CT 06516, USA

\section{Highlights}

- Average energy demands were $6.1 \mathrm{MJ} / \mathrm{kg}$ biochar and $97 \mathrm{MJ} / \mathrm{kg}$ activated carbon

- Cost of biochar lower than activated carbon to adsorb chromium and zinc

- Cost of biochar comparable to activated carbon to adsorb lead and copper

- Biochar has lower impacts than activated carbon even after transportation phase

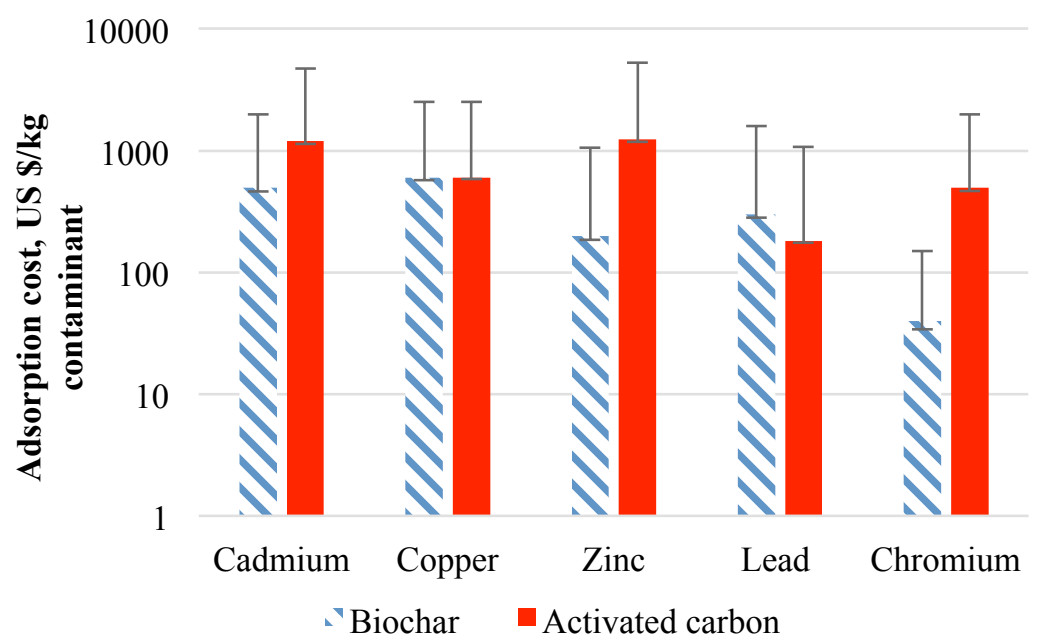

Abstract:

17 As the commercial production and distribution of biochar continues to grow internationally, and its applications

18 diversifying from its early uses as soil amendment, it is important to study the environmental impacts and economic

19 performance of biochar in comparison to activated carbon in order to assess its value. The goal of the study was to

20 assess, through a meta-analysis, the environmental and economic performance of biochar in comparison to activated

21 carbon under an equivalent functional unit to adsorb heavy metals. More than 80 data points on adsorption capacity

22 of biochar and activated carbon were identified through literature, which were statistically analyzed as part of the

23 study. Biochar was found to have lower energy demand and global warming potential impact than activated carbon,

24 where average energy demands were calculated as $6.1 \mathrm{MJ} / \mathrm{kg}$ and $97 \mathrm{MJ} / \mathrm{kg}$ and average greenhouse gas emissions

25 calculated as $-0.9 \mathrm{~kg} \mathrm{CO}_{2} \mathrm{eq} / \mathrm{kg}$ and $6.6 \mathrm{~kg} \mathrm{CO}_{2} \mathrm{eq} / \mathrm{kg}$ for biochar and activated carbon, respectively. When

26 adsorption of heavy metals were used as the functional unit during analysis, results indicate that there is typically an order of magnitude difference between the two materials, where biochar was found to have lower environmental 
impacts. The environmental impact resulting from long distance transportation of biochar would not overturn this conclusion. The adsorption cost of biochar was lower than activated carbon to remove chromium and zinc with a 95\% confidence. Adsorption cost for lead and copper were found to be comparable, and therefore the specific type of biochar and its price could shift results both ways. There is evidence that biochar, if engineered correctly for the task, could be at least as effective as activated carbon and at a lower cost.

\section{Keywords}

35 Biochar; Activated carbon; Heavy metal adsorption; Environmental impact; Economic analysis; Transportation 36 impact.

\section{Introduction}

Biochar is an effective bio-sorbent with a high carbon content varying from $50 \%$ to $93 \%$, produced by pyrolysis of biomass within a closed system with oxygen levels below 0.5\% (Ahmad et al., 2013; Anderson et al.,

41 2013; Antal M.J., Mochidzuki and Paredes, 2003; Clough and Condron, 2010; Inyang et al., 2012; Libra et al., 2011; 42 Liu et al., 2012; Meyer et al., 2012, 2011; Nhuchhen et al., 2014; Roberts et al., 2010; Sohi et al., 2010; Yan et al., 43 2009). Biochar is typically produced from materials that are naturally abundant such as agricultural residue, animal 44 waste, or refuse of woody plants, that have high carbon content. The raw material together with the production 45 technique and temperature has an important effect on product yield and composition (Ahmad et al., 2013; Amutio et 46 al., 2012; Boateng et al., 2010; B. Chen et al., 2011; Chen et al., 2008; X. Chen et al., 2011; Garcia-Nunez et al., 47 2016; Hammond et al., 2011; Harsono et al., 2013; Helleur et al., 2001; Inyang et al., 2012; Kołodyńska et al., 2012; 48 Libra et al., 2011; Liu and Zhang, 2009; Medic, 2012; Mohan et al., 2011; Oleszczuk et al., 2012; Park et al., 2011; 49 Pellera et al., 2012; Regmi et al., 2012; Ro et al., 2010; Roberts et al., 2010; Sohi et al., 2009; Woolf et al., 2010a; 50 Yao et al., 2012, 2011a; P. Zhang et al., 2013).

Traditional processes and technologies that have been utilized for the removal of heavy metals from water

52 and wastewater include chemical precipitation, ion exchange, chemical oxidation and reduction, filtration,

53 membrane technology (separation), reverse osmosis, electrochemical treatment, electrodialysis, electroflotation,

54 electrolytic recovery, and adsorption by activated carbon (El-Ashtoukhy et al. 2008; Inyang et al. 2012; Pellera et al. 55 2012; Zheng et al. 2008). Most of these technologies require high operating energy and thereby cost, and also bring 56 together environmental impacts associated with operating energy consumption.

57 While biochar has been used by humans for centuries as a soil supplement, the material has received 58 recognition in recent years in part due to its adsorption properties, which are claimed to be comparable to activated 59 carbon. Studies suggest that biochar is effective for the removal of heavy metals and other contaminants from 60 municipal wastewater as well as from industrial wastewater (X. Chen et al., 2011; Han et al., 2013; Inyang et al., 61 2012, 2011; Jiang et al., 2012; Karim et al., 2015; Kılıç et al., 2013; Li et al., 2013; Liu and Zhang, 2009; Park et al., 62 2011; Pellera et al., 2012; Pérez-Marín et al., 2007; Regmi et al., 2012; Sun et al., 2011; Tong et al., 2011; Xu et al., 63 2011, 2013; Yao et al., 2011b; P. Zhang et al., 2013; X. Zhang et al., 2013; Zheng et al., 2008). As a result, the 64 commercial production and distribution of biochar continues to grow internationally, and its applications 
diversifying and moving up from its early uses as a soil amendment. To that end, it is important to study the environmental impacts of biochar in comparison to alternative materials such as activated carbon in order to assess its impacts or potential advantages, both from an environmental impact perspective as well as economically.

The goal of the study was to assess, through a meta-analysis, the environmental and economic performance of biochar when used as an adsorbent for heavy metals in comparison to activated carbon. The study enables a comparison between the two materials by using a realistic functional unit for adsorption rather than using mass or volume for comparison. The results of the meta-analysis are statistically stronger than the results of a single study due to increased sample size and data analysis, and as less emphasis is being placed on inherently localized boundaries, materials, and assumptions made in studies. The impact of long distance or international trade on environmental impacts of biochar were also investigated as part of the study.

\section{Methods}

\subsection{Evaluating the environmental impact of biochar and activated carbon}

Data on the environmental impact of biochar and activated carbon were collected mainly through peerreviewed journal articles on life cycle assessment (LCA) of biochar and activated carbon. A total of 84 different

80 types of biochar and activated carbon were identified from literature, and corresponding data recorded. However, as

81 is typical with most LCA studies, the results were based on a particular product, for a specific case. Furthermore, the

82 majority of LCA studies did not report results other than for energy demand and global warming potential (GWP).

83 While there were several data points for photochemical oxidation, acidification, and eutrophication impact

84 categories, they were not sufficient for a statistical analysis and therefore were not included in the scope of the

85 study. A lack of environmental impact data was a big impediment to study other impact categories such as human

86 toxicity; abiotic depletion; ozone layer depletion; and aquatic ecotoxicity.

Conversion factors were necessary to convert units of certain environmental impact categories to known

88 equivalents. GWP of $\mathrm{CH}_{4}$ and $\mathrm{N}_{2} \mathrm{O}$ were calculated by converting their emissions to $\mathrm{CO}_{2}$ equivalent units. The unit 89 conversion factors were taken from the Environment Protection Agency (EPA) report on greenhouse gas (GHG)

90 inventories (EPA 2014). Energy consumption was also converted to $\mathrm{MJ} / \mathrm{kg}$ when reported in other units.

91 Data points for biochar and activated carbon made from similar materials obtained from different sources

92 were condensed to bring down the number of different products to manageable levels. For example, the differences

93 in environmental impacts of early and late corn stover, the main difference being moisture content, were neglected

94 and the two were integrated into one product category as corn stover, as the differences between the two were

95 expected to be negligible when compared to differences among other products, or when compared to activated

96 carbon, the main intent of the study. Similarly, some other studies had analyzed multiple scenarios for the same

97 product based on different intended use, production quantity, or production method, thus presenting multiple data

98 points in each case. In those cases, the range of results was used in the study.

99 The statistical analysis tool @ Risk version 7 was used to analyze environmental impacts of biochar and

100 activated carbon resulting from adsorption of heavy metals. The chi-squared test was used to fit distributions for 101 each set of adsorption capacity and environmental impact. Monte Carlo analysis was conducted to analyze 
102 environmental impacts of biochar and activated carbon resulting from adsorption of heavy metals. Monte Carlo

103 analysis uses random inputs from a given dataset and outputs possible results in the form of probability distribution

104 (Palisade, 2013). This analysis was performed using 10,000 iterations. The results of the simulation for each

105 contaminant were fitted with a distribution to evaluate the environmental impact of biochar and activated carbon per

106 adsorption capacity. The mean for the distributions and a 95\% confidence interval for each heavy metal were also

107 calculated and reported in the study.

108

\subsection{The adsorption capacities of biochar and activated carbon}

110 Some adsorption capacity data were reported in millimoles per kilogram or gram, and these values were

111 converted to milligram per gram $(\mathrm{mg} / \mathrm{g})$. Other physical property or test conditions such as particle size, surface

112 area, concentration of contaminants, $\mathrm{pH}$, and adsorbent dose were also reported in this study.

113 A large number of different raw materials that may be used for biochar production were surveyed from

114 literature rather than limit the study on experimental environmental conditions such as temperature and relative

115 humidity for a specific raw material. There were two reasons behind this decision. The goal of this study was to

116 identify overall trends in data through a meta-analysis for biochar and activated carbon rather than to conduct a LCA

117 for a particular product as a case study. Secondly, there is significant lack of reported data on the effects of these

118 variables on adsorption, especially for biochar. The goal was not to test adsorption for its own sake, but rather to tie

119 performance to environmental and economic value in general terms.

120

\subsection{Evaluating the economic performance of biochar compared to activated carbon}

122 To assess the economic performance of biochar in comparison to activated carbon when used for

123 adsorption purposes, the adsorption capacity of each material together with their market prices were used. The

124 metric used for comparison was therefore US\$(2015)/kg adsorbed material.

125 Current market value prices for different types of biochar and activated carbon were sought during the

126 study. Values reported in scholarly publications and online listing of companies from around the world

127 commercially trading biochar was used to gather market price data (Rasmussen 2014). Most of the companies that

128 were located on the directory were from developed countries; namely the U.S., Canada, Australia, and several

129 Western European countries, and a few were from developing countries such as India and Turkey. All companies

130 listed on the directory were contacted by email to inquire regarding price and raw material used to produce biochar.

131 Most companies sold biochar by volume rather than mass or weight, which was the preferred unit used in

132 this study for adsorption calculations. It was found out that the practical reason for this was to enable biochar to be

133 shipped wet to avoid dust problems that may arise when shipped dry, while the removal of volatile carbon during

134 shipping could also lead to problems in a business transaction if the material were sold by mass. Biochar density

135 data were analyzed statistically to convert volume to mass. Data were analyzed statistically and the mean of the

136 biochar density data was used in this study, thus enabling the conversion of price into US\$(2015)/kg biochar.

137 Similar to adsorption calculations, the statistical analysis tool @Risk version7 was used to compare

138 adsorption cost for heavy metals. The chi-squared test was used to fit distributions for each set of adsorption 
139 capacity and price. After the data sets were converted to distributions, Monte Carlo simulation with 10,000 iterations

140 was used to setup distributions for adsorption cost of biochar and activated carbon for each heavy metal analyzed.

141 The mean for the distributions of adsorption costs and a 95\% confidence interval for each heavy metal were also

142 reported.

143

1442.4 Assessing the impact of long distance trade on environmental performance of biochar

\section{$145 \quad$ 2.4.1 Selecting locations for analysis}

146 Different locations from different continents and regions were used as scenario variables in order to

147 estimate the impact of long distance trade on the environmental performance of biochar. The analysis included

148 fifteen locations, where the majority of locations were chosen based on the directory of companies commercially

149 selling biochar. Three countries which were not in the directory were added to capture remaining regions and

150 continents. While selecting locations for the analysis were intended to cover the majority of potential trade routes,

151 what is important to assess impacts of long distance trade is not the location or the country itself, but the distance

152 between the two locations where transportation occurs.

153

$154 \quad$ 2.4.2 Estimating the distance between selected locations

155 To calculate the added energy consumption and GHG emissions as a result of long distance trade of one

156 metric ton of biochar, land and sea distances between selected locations had to be estimated. For distances that could

157 be traversed by land routes, the publicly available online Google Maps tool was used to estimate distance (Google

158 Maps 2015). For routes that required sea transport, an online resource was used to estimate distances from port to

159 port (Searates 2015). In such cases, the land routes required to transport goods to and from respective ports were

160 also included in the analysis.

161 As the goal of this step of the analysis was to gain insights into the overall impacts of long distance trade on

162 environmental performance, rather than specifically determine impacts for an individual transaction, the center of

163 each state was used to estimate impacts when the locations were inside the U.S. When countries were used, their

164 capital cities were chosen to represent the point of destination and departure for biochar. The distances and impacts

165 reported in this study could be used as a guide to estimate impacts of long distance or international trade that might

166 occur between two other locations not captured by the selected 15 sites in the analysis, but with comparable

167 distances between them, as impacts calculated here were dependent on distance and mode of travel rather than

168 country or continent. The wide array of locations from across the globe was chosen with that additional intent.

169

170

171

\subsubsection{Calculating energy demand}

172 transportation. Energy intensity of sea transportation was taken as $0.14 \mathrm{MJ} / \mathrm{ton}-\mathrm{km}$ based on literature (Davis et al.,

173 2014). Trucks rather than rail were assumed for land transportation initially. A fuel consumption factor of 15.3 liter

174 per thousand ton-km was used for class 8 truck transport, which uses diesel fuel, and includes combination trucks

175 and tractor-trailers among other more specific uses (Davis et al., 2014). The fuel consumption factor was converted 
176 to truck transportation energy intensity by multiplying by the low heat value for diesel, which was found to be

177 128,450 Btu/gallon diesel (Boundy et al. 2011; DOE 2014). The resulting energy intensity of $0.55 \mathrm{MJ} /$ ton-km was

178 used in the calculations thereafter. Multiplying the land distance by the energy intensity provided the energy

179 required to transport biochar by trucks. Total transportation energy consumption was found by adding together the

180 energy consumptions of sea and land transportation.

181 A further analysis was conducted to test the effect of using the center of states in the U.S. on the impact

182 resulting from transportation. Farther and nearer points on the border of the states, rather than the center point of the

183 state, were selected to check their effect on the values of energy demand and GHG emissions. The effect of using

184 truck rather than rail for transportation over land was also investigated through a sensitivity analysis.

\subsubsection{Calculating greenhouse gas emissions}

187 GHG emissions of transportation were calculated by using emission factors for GHG inventories used by

188 the EPA (EPA 2014). The cumulative GHG emitted from waterborne craft were estimated by multiplying the

189 nautical distance between ports with the transportation emission factor, which was $0.026 \mathrm{~kg} \mathrm{CO}_{2}$ eq. per ton-km

190 (EPA 2014). GHG emissions of truck transportation were calculated by multiplying the land distance by $0.185 \mathrm{~kg}$

$191 \mathrm{CO}_{2}$ eq. per ton-km (EPA 2014). The two values for the two respective modes of transport were added together to

192 estimate GHG emissions resulting from long distance or international trade of biochar among selected locations.

194 3. Results and discussion

\subsection{Environmental impact of biochar compared with activated carbon}

196 Environmental impact data related to the production of biochar and activated carbon reviewed from

197 literature were used for comparison. Energy demand and GWP were two categories considered in this study, and

198 results were summarized in Table 1. Although environmental impact data based on different raw materials used for

199 production of activated carbon were limited, a diverse list was found for raw materials that can be used for biochar

200 production including many types of organic wastes, woods and residual plants that indicate increased adaptability of

201 biochar production to local conditions.

Table 1. Energy demand and global warming potential of biochar and activated carbon. Values for energy demand indicate production energy unless noted otherwise. (Bartocci et al., 2016; Bayer et al., 2005; Dang et al., 2015; Gabarrell et al., 2012; Gaunt and Lehmann, 2008; Hammond et al., 2011; Hjaila et al., 2013; Ibarrola et al., 2011; Johnsen et al., 2016; Meyer et al., 2012; Muñoz et al., 2007; Peters et al., 2015; Roberts et al., 2010; Sparrevik et al., 2013; Woolf et al., 2010b).

\begin{tabular}{lll}
\hline Material Type & Energy demand, MJ/kg & $\begin{array}{l}\text { Global Warming Potential, } \\
\mathbf{k g ~ C O} \mathbf{C}_{2} \mathbf{e q} / \mathbf{k g}\end{array}$ \\
\hline Activated carbon (Virgin), hard coal & $44^{\mathrm{a}}$ & $3,3^{\mathrm{a}}, 8,11$ \\
Activated carbon, olive-waste & 170 & 11 \\
Activated carbon, Recycled & & 1.2 \\
Activated carbon, Granular & 79.8 & 9.3 \\
Agroforestry biochar & & -0.2 \\
Anaerobic digestion biochar & $1.1^{\mathrm{a}, \mathrm{b}}$ & -0.7 \\
Barley straw biochar & $1.1-2.2^{\mathrm{b}}$ & $-0.7--0.9$ \\
\hline
\end{tabular}




\begin{tabular}{lll}
\hline Biomass crops biochar (herbaceous) & & -0.2 \\
Biomass crops biochar (woody) & & -0.2 \\
Canadian forestry residue chips biochar & $1.4-2.9^{\mathrm{b}}$ & $-0.9-1.1$ \\
\hline Cardboard biochar & $1.8^{\mathrm{a}, \mathrm{b}}$ & -0.1 \\
Cattle manure biochar & & -0.2 \\
\hline Cereals excluding rice biochar & & $-0.2--0.1$ \\
Corn Stover biochar & $0.84,1.5-3^{\mathrm{a}}, 8$ & $-0.7--0.8,-4--2$ \\
Dense refuse derived fuel & $1.8^{\mathrm{a}, \mathrm{b}}$ & -0.3 \\
\hline Food waste biochar & $1.3^{\mathrm{a}, \mathrm{b}}$ & -1.1 \\
\hline Forestry residue chips biochar & $1.4-2.9^{\mathrm{b}}$ & $-1.3--1.1,-0.2--0.1$ \\
Green waste biochar & $1.8^{\mathrm{a}, \mathrm{b}}$ & $-1.1,-0.3$ \\
\hline Maize cobs biochar & & $-0.1-0.1$ \\
Miscanthus biochar & $1.4-2.9^{\mathrm{b}}, 10$ & $-3.5--3.1,-1--1.2,-0.6$ \\
Paper sludge biochar & $1.1^{\mathrm{a}, \mathrm{b}}$ & -0.7 \\
\hline Pig manure biochar & & -0.4 \\
\hline Poplar biochar & 16 & -1.2 \\
Poultry litter biochar & $1.1^{\mathrm{a}, \mathrm{b}}$ & $-0.5,-0.2$ \\
\hline Rice biochar & & -0.4 \\
\hline Sewage sludge biochar & $1.8^{\mathrm{a}, \mathrm{b}}$ & -0.8 \\
\hline Sugarcane biochar & & -0.2 \\
\hline Switch grass biochar & $1.5^{\mathrm{a}}, 11$ & $-2.8--2.5,-0.4-0$ \\
\hline Wheat straw biochar & $1.1^{-2.2^{\mathrm{b}}}, 8.3$ & $-2.1--1.9,-0.9--0.7,-0.7$ \\
\hline Whisky draff biochar & $1.1^{\mathrm{a}, \mathrm{b}}$ & -0.8 \\
\hline Wood waste biochar & $2.1^{\mathrm{a}, \mathrm{b}}$ & $-1.3,-0.2$ \\
\hline Yard waste biochar & $3^{\mathrm{a}}$ & -0.9 \\
\hline
\end{tabular}

${ }^{\mathrm{a}}$ Estimated from figure, ${ }^{\mathrm{b}}$ Produced energy.

It is important to note that almost all of the studies reported negative values for GWP associated with

211 biochar production due to carbon abatement ability of biochar, with average emissions calculated as $-0.9 \mathrm{~kg}$

$212 \mathrm{CO}_{2} \mathrm{eq} / \mathrm{kg}$, as compared to $6.6 \mathrm{~kg} \mathrm{CO}_{2} \mathrm{eq} / \mathrm{kg}$ for activated carbon. The average energy demands of biochar and

213 activated carbon production were found to be $6.1 \mathrm{MJ} / \mathrm{kg}$ and $97 \mathrm{MJ} / \mathrm{kg}$, respectively, indicating an order of

214 magnitude difference between the two materials.

for various adsorbed materials were presented in Table A1 together with particle size, surface area, $\mathrm{pH}$, contaminant concentration, adsorbed material and dose, and contact time reported in each study.

\subsubsection{Adsorption capacity of biochar and activated carbon}

When compared on a per mass basis as in Table A1, adsorption capacity of biochar to remove cadmium and copper from water were in general found to be higher than those of activated carbon, whereas a significant difference could not be observed for chromium. Other heavy metals presented mixed results. However, data frequently included large reported ranges for adsorption capacity, thereby eliminating the possibility of making statistically significant conclusions. Adsorption capacity of biochar ultimately depends on multiple factors including the type of raw material used. While careful selection of one type of biochar may provide superior adsorption performance over activated carbon, another type of biochar may have just the opposite effect. Similarly, particle size, surface area, $\mathrm{pH}$, contaminant concentration, adsorbed material and dose, and contact time are other factors that need to be considered. 
A sensitivity analysis was conducted based on physical properties and experimental data reported in Table

230 A1. The effects of the following factors were investigated: particle size; surface area; $\mathrm{pH}$; contaminant

231 concentration; adsorbent dose; and contact time. Among these, surface area provided a reasonable degree of

232 correlation with adsorption capacity, and its influence was further investigated and results presented in Figure 1.

233 While a positive correlation was observed between surface area and adsorption capacity for chromium, zinc, and

234 lead, a clear positive correlation could not be observed for cadmium and copper based on data surveyed through

235 literature. In fact, data through existing literature suggests that adsorption capacity of cadmium and copper tend to

236 decline as surface area increases. However, high adsorption capacities reported at relatively small surface areas may

237 indicate underlying mechanisms that may be equally effective in determining adsorption. Some studies indicate that

238 adsorption capacity of biochar depend on ion exchange as the dominating mode by which biochar adsorb metal ions

239 rather than physical properties of the adsorbent (Mohan et al. 2007; Tong et al. 2011; Xu et al. 2013).

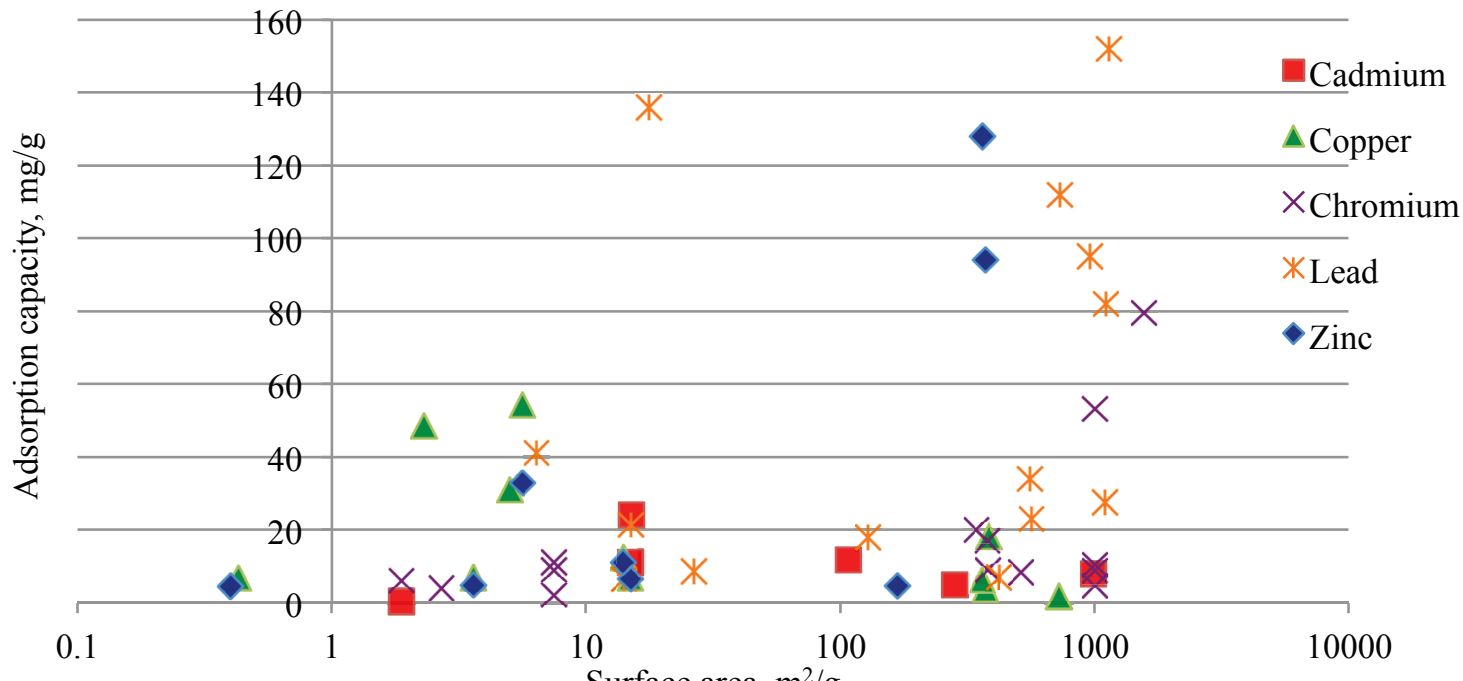

Surface area, $\mathrm{m}^{2} / \mathrm{g}$

243 scale was used for the $\mathrm{x}$-axis corresponding to surface area. Where a positive correlation was observed for

244 Chromium, Lead, and Zinc, no clear correlation was observed for Cadmium and Copper.

When adsorption of heavy metals by biochar and activated carbon are compared on a per mass of adsorbent

247 basis, results indicate that adsorption capacity of biochar can compete with or exceed activated carbon for

248 contaminants analyzed. However, a raw material that outperformed the other in all categories could not be found.

249 Therefore, if faced with a choice between activated carbon and biochar, the answer would lie in understanding the

250 intended use; the intended contaminant or the mix of materials to be adsorbed. Engineered systems to adsorb

251 contaminants could then be optimized by selecting raw materials that perform best in each category. 
As the main goal of adsorbent materials are to remove contaminants, heavy metals in this case, an appropriate functional unit for the comparison of environmental impact of biochar and activated carbon would be impacts per mass of contaminant removed, rather than impacts per mass of adsorbent material. Therefore, the two metrics of $\mathrm{MJ} / \mathrm{kg}$ contaminant, and $\mathrm{kg} \mathrm{CO}_{2} \mathrm{eq} / \mathrm{kg}$ contaminant were used to compare the two materials. Statistical distributions combined with a Monte Carlo analysis yielded the results presented in Figures 2 and 3 together with the indicated $95 \%$ confidence interval.

Figure 2 indicate that the energy demand for biochar is significantly lower than activated carbon for most heavy metals. Only in the case of lead adsorption, the figure illustrates that the difference in confidence intervals is not large enough to warrant a clear answer.

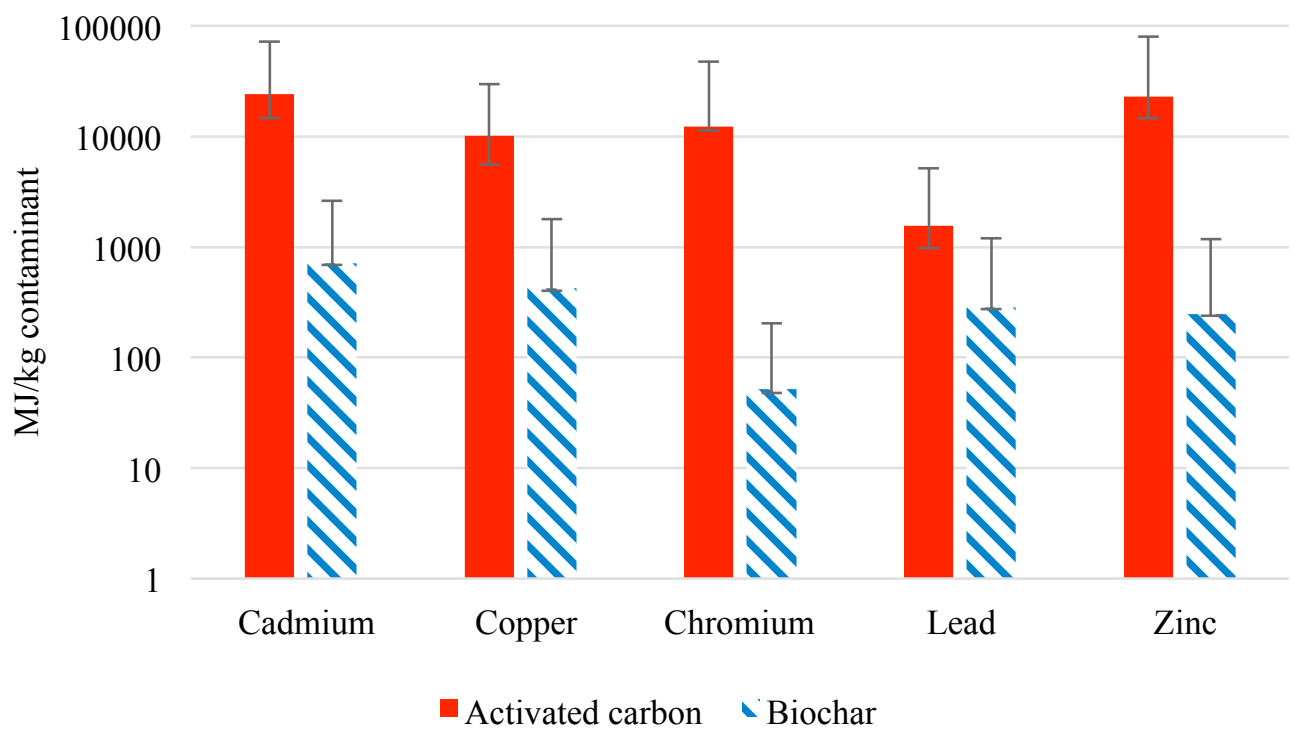

Figure 2. Energy demand for adsorption of heavy metals by biochar and activated carbon. Bars indicate the mean, and the error bars indicate the $95 \%$ confidence interval of results. metals by activated carbon are higher than GHG emissions of biochar. The differences were found to be statistically significant. It is interesting to note that biochar has a negative emissions value for all the heavy metals studied due to its ability to sequester carbon. 


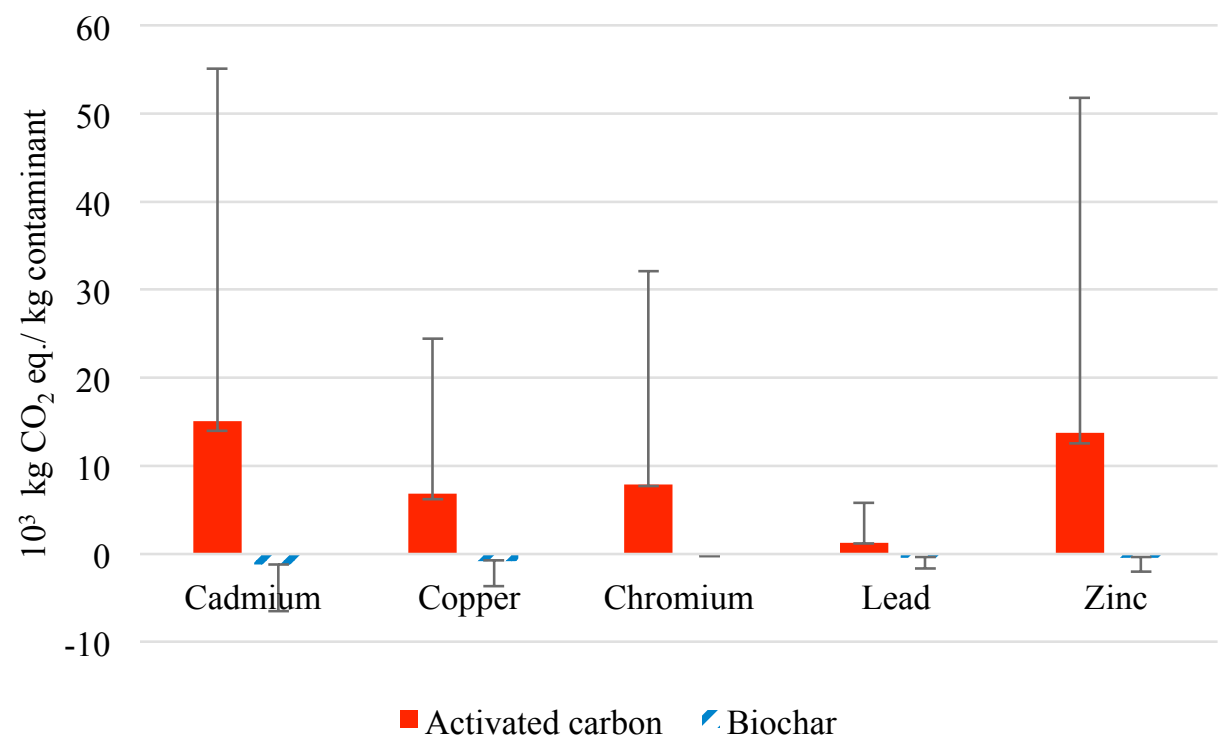

274 Figure 3. Greenhouse gas emissions resulting from adsorption of heavy metals by biochar and activated carbon.

275 Bars indicate the mean, and the error bars indicate the $95 \%$ confidence interval of results.

While energy required to produce activated carbon is many times more than the energy demand to produce the same amount of biochar, typically, spent activated carbon is not disposed of but regenerated for reuse. It was deemed necessary to factor this life cycle stage into the analysis. Regeneration process was reported to require about $50 \%$ of the energy demand of activated carbon during its production. It is important to note that activated carbon loses about $10 \%$ of its weight during each regeneration process (Muñoz et al. 2007). production based on the adsorption capacity to remove heavy metals. In the case of copper for example, activated carbon needs to be regenerated twice before biochar would be replaced and discarded due to the higher adsorption capacity of biochar to remove copper. Energy demand distributions for activated carbon and biochar that were setup based on data points presented in Table 1 were used to test the impact of regeneration on results. The average energy demand in $\mathrm{MJ} / \mathrm{kg}$ adsorbent, and a $95 \%$ confidence interval were used to compare results. Figure 4 illustrates that energy demand of biochar is not expected to meet or exceed energy demand of activated carbon for copper adsorption even when the regeneration capabilities of activated carbon is taken into account. Similar results were obtained for the other heavy metals analyzed, where energy demand of biochar was not expected to match the energy demand of activated carbon. 


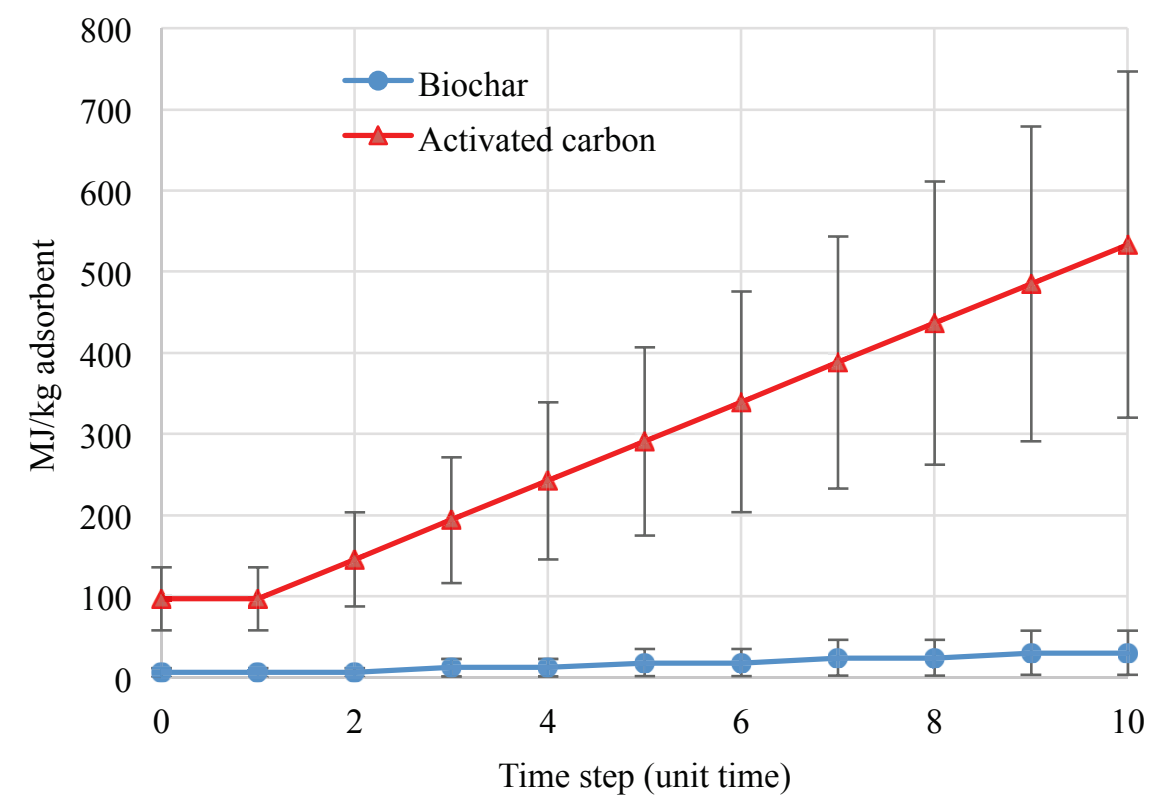

Time step (unit time)

Figure 4. Energy demand to produce and regenerate biochar and activated carbon for copper adsorption. Error bars 297 indicate the $95 \%$ confidence interval for results.

\subsection{Economic performance of biochar as an adsorbent compared to activated carbon}

The economic performance of biochar and activated carbon when used as a sorbent were compared as part of the study. Their performances were evaluated based on adsorption capacity and current commercial price of each material to calculate effective adsorption cost. Biochar produced from different raw materials were analyzed separately.

\subsubsection{Biochar density}

Market prices of biochar were either reported by mass or by volume by commercial companies. The unit discrepancy required an additional density calculation to convert volume to mass, to compare prices and feasibility of different alternative materials to be used as an adsorbent in units of $\$ / \mathrm{kg}$. Bulk density of biochar ranged between 0.1-1.1 Mg/m $\mathrm{m}^{3}$ based on 20 datapoints as shown in Table 2 (Anderson et al. 2013; Beesley and Marmiroli 2011; Berger 2012; Downie 2011; Mahimairaja 2012; Mohan et al. 2011; Nhuchhen et al. 2014; Shackley et al. 2010). Data were analyzed statistically and a triangular distribution with a mean of 0.47 was fitted to the dataset. The mean value of $0.47 \mathrm{Mg} / \mathrm{m}^{3}$ was also used to represent the density of biochar in this study to convert unit volume to unit mass. 
318 Table 2. Density of biochar produced from different raw materials

\begin{tabular}{lll}
\hline Biochar Type & Density, Mg/m & Source \\
\hline Switch grass & 0.11 & (Nhuchhen et al., 2014) \\
Forest residues & 0.16 & (Anderson et al., 2013) \\
Mill residues & 0.16 & (Anderson et al., 2013) \\
Raw pine & 0.16 & (Nhuchhen et al., 2014) \\
Balsa & $0.16^{*}$ & (Downie, 2011) \\
Sweet gum & 0.18 & (Nhuchhen et al., 2014) \\
Chopped salix biochar & 0.27 & (Berger, 2012) \\
Redwood & $0.3^{*}$ & (Downie, 2011) \\
Biochar & 0.3 & (Beesley and Marmiroli, 2011) \\
White pine & $0.35^{*}$ & (Downie, 2011) \\
Different woods & 0.36 & (Downie, 2011) \\
Biochar & 0.4 & (Shackley et al., 2010) \\
Basswood & $0.4^{*}$ & (Downie, 2011) \\
Biochar & 0.45 & (Mahimairaja, 2012) \\
Oak bark & 0.57 & (Mohan et al., 2011) \\
Red oak & $0.6^{*}$ & (Downie, 2011) \\
Hard maple & $0.6^{*}$ & (Downie, 2011) \\
Biomass & 0.77 & (Nhuchhen et al., 2014) \\
Oak wood & 0.91 & (Mohan et al., 2011) \\
Lignum vitae & $1.1^{*}$ & (Downie, 2011) \\
\hline
\end{tabular}

*Estimated from figure

\section{3.2.2 Unit price of biochar and activated carbon}

322 A realistic evaluation of the cost of biochar and activated carbon used as a sorbent required commercial

323 price of products to be used together with their adsorption capacity to estimate the cost of adsorbing a given amount

324 of contaminant or material. Current biochar prices were collected through companies in different countries and 325 converted to US $\$ / \mathrm{kg}$, together with a few data points from published literature. The commercial price of biochar 326 ranged between $\$ 0.8-18 / \mathrm{kg}$ based on 14 data points, as presented in Table 3. It is interesting to note that biochar 327 prices obtained from literature were significantly lower than commercial prices, where literature reported values as 328 low as $\$ 0.05 / \mathrm{kg}$, and hence were excluded from the study. Activated carbon prices obtained from literature and 329 commercial sources ranged between $\$ 0.34-22 / \mathrm{kg}$ based on 13 data points. The average cost of activated carbon and 330 biochar were calculated to be $\$ 5.6$ and $\$ 5$, respectively. The standard deviation was calculated as 7.5 for price of 331 activated carbon, and 5.26 for price of biochar. International Biochar Initiative, a non-profit organization dedicated 332 to promoting biochar research and commercialization, report biochar price to be $\$ 3.08 / \mathrm{kg}$ in 2014 based on the 333 average cost of 56 products (IBI, 2014). While further detailed information on the types of biochar or the

334 distribution of values were not available, comparing the confidence interval calculated in this study to their reported 335 value provides further credence to the range of results presented in this study.

336 A hypothesis test carried out to test whether there was a significant difference in the average price of 337 biochar and activated carbon concluded that there was not sufficient evidence to prove that the average prices were 338 significantly different at the $95 \%$ confidence interval. 
Table 3. Unit price of biochar and activated carbon. Commercial prices reflect 2015 prices in US Dollars. (Alibaba.com, 2015; Amazon.com, 2015; Babel and Kurniawan, 2004; Gaunt and Lehmann, 2008; Grassi et al.,

343 2012; Johnsen et al., 2016; Mohan et al., 2011; Rasmussen, 2011; Slaughter, 2011)

\begin{tabular}{|c|c|c|}
\hline Material Type & Location & US\$/kg \\
\hline Activated Carbon (granular) & $\mathrm{N} / \mathrm{A}$ & 6.4 \\
\hline Activated carbon (Coconut shell charcoal oxidized with nitric acid) & $\mathrm{N} / \mathrm{A}$ & 0.3 \\
\hline Activated carbon (Commercial) & $\mathrm{N} / \mathrm{A}$ & 21 \\
\hline Activated carbon (Coconut shell) & $\mathrm{N} / \mathrm{A}$ & 2.2 \\
\hline Activated carbon (Coconut shell charcoal) & $\mathrm{N} / \mathrm{A}$ & 0.3 \\
\hline Activated carbon (Coconut shell) & China & $1.5-3$ \\
\hline Activated carbon (Commercial oxidized with nitric acid) & $\mathrm{N} / \mathrm{A}$ & 1.4 \\
\hline Activated carbon (Commercial type Filtrasorb-400) & $\mathrm{N} / \mathrm{A}$ & $20-22$ \\
\hline Activated carbon (Commercial) & $\mathrm{N} / \mathrm{A}$ & 1.4 \\
\hline Activated carbon (Granular) & $\mathrm{N} / \mathrm{A}$ & 2.2 \\
\hline Activated carbon (Granular) & Oklahoma & 3.2 \\
\hline Activated carbon (Powdered) & Oklahoma & $1.2-2$ \\
\hline Activated Carbon (Granular, Coconut) & Illinois, USA & 9.2 \\
\hline Bamboo biochar & Alabama, USA & $7 *$ \\
\hline Coconut shell biochar & USA & 0.8 \\
\hline Coppiced hardwoods biochar & UK & 1.6 \\
\hline Corn debris, manure, and forestry debris (activated biochar) & Idaho, USA & $2 *$ \\
\hline Corn debris, manure, and forestry debris (raw biochar) & Idaho, USA & $1.5^{*}$ \\
\hline Hardwood biochar & Australia & $2.3^{*}$ \\
\hline Mixed hardwood and softwood biochar & Central Canada & $1 *$ \\
\hline Pinewood biochar & Missouri, USA & 0.9 \\
\hline Pinewood biochar & & $0.9-1.9$ \\
\hline Pinewood biochar (Organic conifer biomass) & Oregon, USA & $8.3 *$ \\
\hline Softwood chips Biochar & California USA & 3.5 \\
\hline Softwoods mix with Pine, Spruce, Fir and Cedar biochar & Vermont, USA & $7.2 *$ \\
\hline Tree branches biochar & Kansas, USA & 11 \\
\hline Virgin wood feedstock biochar & Massachusetts, USA & 17.8 \\
\hline
\end{tabular}

* Product sold by volume rather than mass - conversion to $\$ / \mathrm{kg}$ according to calculated mean density of $0.47 \mathrm{Mg} / \mathrm{m}^{3}$

\subsubsection{Economic performance of biochar and activated carbon when utilized as an adsorbent}

One of the main goals of the study was to compare the economic performance of biochar and activated carbon when used as an adsorbent, rather than costs per mass or volume. Therefore, economic performance of materials as an adsorbent were evaluated by analyzing adsorption capacity of the alternatives and their commercial prices.

Economic analysis included defining and evaluating distributions to seek overall trends in performance, rather than investigate a specific adsorbent or raw material used. Monte Carlo simulation was used to estimate and compare the cost of heavy metal adsorption by biochar and activated carbon. A representative outcome was presented in Figure 5, where adsorption cost to remove copper is being displayed. Results indicate that a significant difference between biochar and activated carbon does not exist to adsorb a unit mass of copper. The result was 
358 further supported by Figure 6, which presents the mean values of the distributions together with a 95\% confidence 359 interval. In the case of copper, both mean values fall at around $\$ 600 / \mathrm{kg}$ copper and the range of results seem to 360 overlap, indicating a significant difference was not expected.

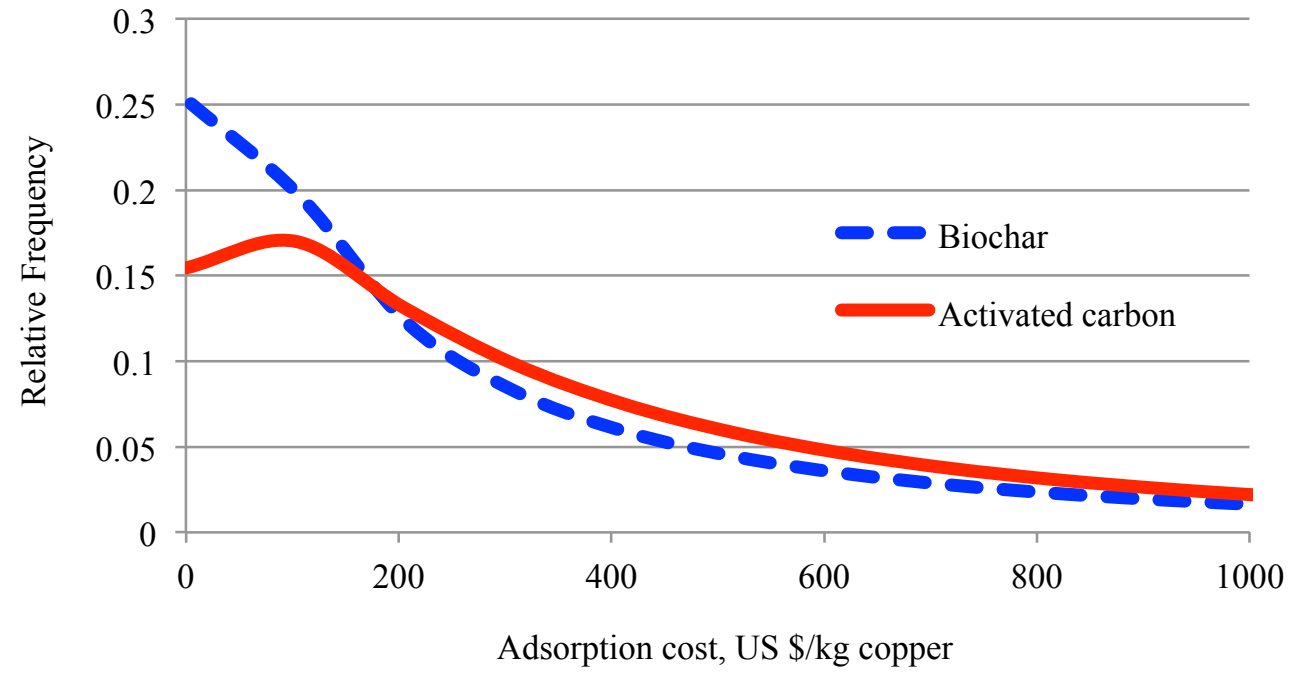

363 Figure 5. Adsorption cost distribution for copper removal using biochar and activated carbon. Results indicate that a

364 significant difference between biochar and activated carbon does not exist to adsorb a unit mass of copper.

Similarly for adsorbing lead, Figure 6 indicates that biochar, on average, is likely to be more expensive than activated carbon as the means of the distributions were $\$ 300 / \mathrm{kg}$ lead for biochar and $\$ 180 / \mathrm{kg}$ lead for activated carbon. The confidence intervals also indicate a near overlap, thereby supporting the conclusion that the two materials perform comparably.

372 and activated carbon, respectively, and as there was no overlap of the confidence intervals indicating statistical

373 significance. In this case, it can be concluded that adsorption cost to remove zinc was lower for biochar than 374 activated carbon.

Figure 6 also indicates a similar, but larger difference between the adsorption cost to remove chromium.

376 Beyond a difference in their mean values of $\$ 40 / \mathrm{kg}$ and $\$ 500 / \mathrm{kg}$ for biochar and activated carbon, respectively, the 377 range of results do not overlap at the $95 \%$ confidence interval. Similar to the case for zinc, it can be concluded that 378 adsorbing chromium by biochar could be economically advantageous than using activated carbon. 
10000

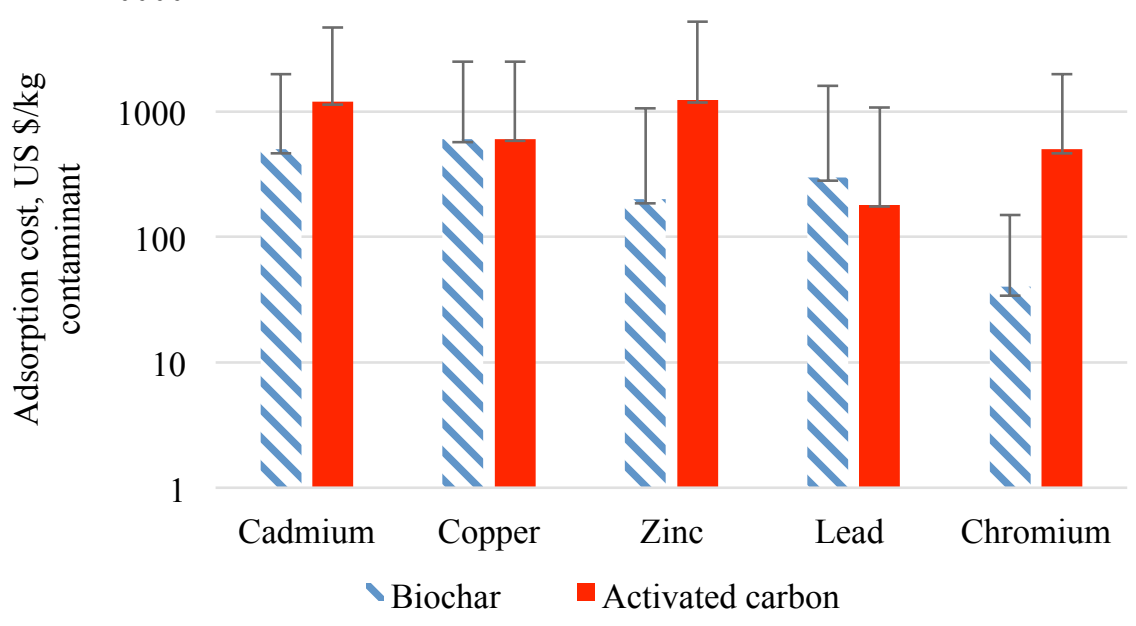

Figure 6. The cost of adsorbing heavy metals by biochar and activated carbon. Bars indicate the mean, and the error bars indicate the $95 \%$ confidence interval of results.

Biochar is an effective biosorbent due to its efficiency in removing a variety of materials from aqueous solutions, both in terms of technical and economic performance. In adsorption performance comparison, biochar was generally found to be less costly than activated carbon to remove different adsorbed materials. However, the ultimate decision on alternative materials must be evaluated on a case by case basis, based on the availability of types of biochar from different raw materials, as well as the contaminant or material mix to be adsorbed.

Results presented in this section were intended to identify general trends in the comparative economic performance of biochar and activated carbon for adsorption. Uncertainty introduced by variations in biochar properties and the varying nature of market prices for commercial products should be kept in perspective while extrapolating results presented here.

\subsection{Impact of long distance trade on environmental performance of biochar}

Another goal of the study was to assess the environmental impacts resulting from long distance or international trade of biochar. The impact of international trade on biochar was evaluated based on GHG emissions and energy demand to transport biochar via land or waterways. The aim of this step of the analysis was to identify the magnitude of impact caused by long distance transportation, rather than precisely calculate impacts, which could only be possible when the origin, destination, and mode of transportation were known. The environmental impact of international trade was quantified to compare with impacts deriving from the production phase. In other words, would the environmental performance of biochar still be better than activated carbon even when the former was obtained internationally over long distances and the latter obtained locally.

Estimate distances between 15 locations, representative of every continent, region, or major biochar

404 company locate during this study were used, as exact numbers can only be determined when there are specified

405 buyers and sellers. Such distances represent the distance from the center of a city or state to the center of the other

406 location. Among modes of transportation, truck was chosen over rail as its energy demand and environmental 
407 impacts are higher, thereby resulting in a worst case scenario. Waterborne transportation was assumed for intercontinental shipments. Distance between two locations, energy consumption, and GHG emissions resulting from the modeled transportation are presented in Tables B1-3.

International trade of biochar was found to slightly affect its environmental performance, but the gap is still

411 large when compared to the impact resulting from the production of activated carbon. Thus, the potential increase in 412 energy consumed resulting from long distance or international trade is about $35 \%$ of the energy demand to produce

$4131 \mathrm{~kg}$ of biochar. In terms of GHG emissions, long distance trade eliminates the role of biochar to sequester carbon,

414 hence the average emissions value of $-0.9 \mathrm{~kg} \mathrm{CO}_{2} \mathrm{eq} / \mathrm{kg}$ would become zero. Still, biochar was found to have lower

415 GHG emissions than activated carbon when transported between selected locations.

416 Results indicate that biochar may be shipped several times around the globe before balancing the impact

417 resulting from production and activation of activated carbon. Activated carbon would become favorable in terms of

418 GHG emissions if it were obtained locally and biochar were transported more than 40,200 km over land by trucks or

419 more than $274,000 \mathrm{~km}$ over waterways. Considering that the Earth's circumference is about 40,000 km, transporting

420 goods over such distances may not be necessary or practical.

\subsection{Barriers that may prevent biochar to replace activated carbon in adsorption applications}

Today, activated carbon is the most common adsorbent used. Results of this study, however, indicate that activated carbon may not always be the most effective, nor the least costly option for adsorption purposes. For certain materials and contaminants, biochar on average proved to have comparable or better adsorption capacity and improved economic performance. There is some literature discussing the potential application of biochar for water treatment purposes, but no major commercial applications exist yet. There are real or perceived barriers that needs to be resolved before biochar may be expected to replace activated carbon such as:

- Although biochar removes some contaminants more effectively than activated carbon, the adsorption efficiency of biochar is not stable but fluctuates, whereas activated carbon has a more stable and predictable efficiency (Berger 2012).

- Biochar may take longer than activated carbon to adsorb contaminants when same amounts of the two

441 correctly for the task, could be at least as effective as activated carbon, at a lower cost. However, there are still

442 technical barriers preventing its widespread implementation. Further research along identified areas could return 443 significant environmental, economic, and societal benefits. 


\section{Conclusion}

The main goal of the study was to conduct a meta-analysis to evaluate the environmental and economic

447 performance of biochar in comparison to activated carbon. The impact long distance trade would have on

448 environmental impacts of biochar were also investigated as part of the study. A discussion on some of the barriers

449 that prevent the use of biochar adsorption applications was also presented.

Due to a lack of data regarding full environmental impacts of biochar from LCA studies, the environmental

451 focus of the study was mainly on the most commonly reported environmental impacts of energy demand and GWP.

452 Data in these categories indicate that biochar has lower environmental impact than activated carbon. For GHG

453 emissions, biochar on average was found to have negative emissions of $-0.9 \mathrm{~kg} \mathrm{CO}_{2} \mathrm{eq} . / \mathrm{kg}$ due to its ability to

454 sequester carbon, while activated carbon demonstrated higher on average $\mathrm{GHG}$ emissions of $6.6 \mathrm{~kg} \mathrm{CO}{ }_{2} \mathrm{eq} . / \mathrm{kg}$. The

455 average energy consumption to produce $1 \mathrm{~kg}$ of activated carbon and biochar was calculated to be $97 \mathrm{MJ} / \mathrm{kg}$ and 6.1

$456 \mathrm{MJ} / \mathrm{kg}$, respectively.

457 An evaluation of the economic performance of biochar and activated carbon demonstrated that the average

458 cost of activated carbon and biochar were $\$ 5.6 / \mathrm{kg}$ and $\$ 5 / \mathrm{kg}$, respectively. These unit prices however, need to be

459 combined with adsorption capacities to yield information on the cost of contaminant removal. The adsorption cost of

460 biochar was lower than activated carbon to remove chromium and zinc with a $95 \%$ confidence. Adsorption cost for

461 lead and copper were found to be comparable, and results cannot be generalized as the type of biochar and its price

462 could take results both ways and therefore more specific testing is recommended.

463 The environmental impact resulting from long distance transportation of biochar was assessed. While

464 results demonstrate that long distance trade of biochar could affect its environmental impacts somewhat, the gap is

465 still large when compared to activated carbon production. Transportation distances required to overturn this

466 conclusion were not practical. These results indicate that biochar would still have less environmental impact than

467 activated carbon even if it were transported over long distances.

468 Obstacles that may prevent application of biochar as a replacement to activated carbon were also discussed

469 within the study. Among these reasons, variations in material property, especially variations due to use of different

470 raw materials are major hindrances. Still, engineered products that contain a mix of different types of biochar may

471 be optimized for adsorption applications.

\section{Acknowledgements}

474 This research did not receive any specific grant from funding agencies in the public, commercial, or not-

475 for-profit sectors. 


\section{References}

Ahmad, M., Lee, S.S., Rajapaksha, A.U., Vithanage, M., Zhang, M., Cho, J.S., Lee, S.E., Ok, Y.S., 2013. Trichloroethylene adsorption by pine needle biochars produced at various pyrolysis temperatures. Bioresour. Technol. 143, 615-622. doi:10.1016/j.biortech.2013.06.033

Alibaba.com, 2015. Cheap Shell granular coconut activated carbon [WWW Document].

Amazon.com, 2015. Premium Bulk Granular Activated Carbon 55 Lb. Sack [WWW Document]. Ind. filter sales.

Amutio, M., Lopez, G., Artetxe, M., Elordi, G., Olazar, M., Bilbao, J., 2012. Influence of temperature on biomass pyrolysis in a conical spouted bed reactor. Resour. Conserv. Recycl. 59, 23-31. doi:10.1016/j.resconrec.2011.04.002

Anderson, N., Jones, J.G., Page-Dumroese, D., McCollum, D., Baker, S., Loeffler, D., Chung, W., 2013. A comparison of producer gas, biochar, and activated carbon from two distributed scale thermochemical conversion systems used to process forest biomass. Energies 6, 164-183. doi:10.3390/en6010164

Antal M.J., Mochidzuki, K., Paredes, L.S., 2003. Flash Carbonization of Biomass. Ind. Eng. Chem. Res. 42, 36903699. doi:10.1021/ie0301839

Babel, S., Kurniawan, T.A., 2004. Cr(VI) removal from synthetic wastewater using coconut shell charcoal and commercial activated carbon modified with oxidizing agents and/or chitosan. Chemosphere 54, 951-967. doi:10.1016/j.chemosphere.2003.10.001

Bartocci, P., Bidini, G., Saputo, P., Fantozzi, F., 2016. Biochar Pellet Carbon Footprint. Chem. Eng. Trans. 50, 217222.

Bayer, P., Heuer, E., Karl, U., Finkel, M., 2005. Economical and ecological comparison of granular activated carbon (GAC) adsorber refill strategies. Water Res. 39, 1719-1728. doi:10.1016/j.watres.2005.02.005

Beesley, L., Marmiroli, M., 2011. The immobilisation and retention of soluble arsenic, cadmium and zinc by biochar. Environ. Pollut. 159, 474-480. doi:10.1016/j.envpol.2010.10.016

Berger, C., 2012. Biochar and activated carbon filters for greywater treatment - comparison of organic matter and nutrients removal. Swedish University of Agricultural Sciences, Uppsala, Sweden.

Boateng, A.A., Mullen, C.A., Goldberg, N.M., Hicks, K.B., Devine, T.E., Lima, I.M., McMurtrey, E., J., 2010. Sustainable production of bioenergy and biochar from the straw of high-biomass soybean lines via fast pyrolysis. Environ. Prog. Sustain. Energy 29, 175-183. doi:10.1002/ep.10446

Boundy, B., Diegel, S.W., Wright, L., Davis, S.C., 2011. Biomass Energy Data Book, 4th ed, Oak Ridge National Laboratory. U.S. Department of Energy, Oak Ridge, TN.

Cao, X., Ma, L., Gao, B., Harris, W., 2009. Dairy-manure derived biochar effectively sorbs lead and atrazine. Environ. Sci. Technol. 43, 3285-3291. doi:10.1021/es803092k

Chen, B., Chen, Z., Lv, S., 2011. A novel magnetic biochar efficiently sorbs organic pollutants and phosphate. Bioresour. Technol. 102, 716-723. doi:10.1016/j.biortech.2010.08.067

Chen, B., Zhou, D., Zhu, L., 2008. Transitional adsorption and partition of nonpolar and polar aromatic contaminants by biochars of pine needles with different pyrolytic temperatures. Environ. Sci. Technol. 42, 5137-5143. doi:10.1021/es8002684

Chen, X., Chen, G., Chen, L., Chen, Y., Lehmann, J., McBride, M.B., Hay, A.G., 2011. Adsorption of copper and zinc by biochars produced from pyrolysis of hardwood and corn straw in aqueous solution. Bioresour. Technol. 102, 8877-8884. doi:10.1016/j.biortech.2011.06.078

Clough, T.J., Condron, L.M., 2010. Biochar and the nitrogen cycle: introduction. J. Environ. Qual. 39, $1218-1223$. doi: $10.2134 /$ jeq2010.0204

Dang, Q., Mba Wright, M., Brown, R.C., 2015. Ultra-Low Carbon Emissions from Coal-Fired Power Plants through Bio-Oil Co-Firing and Biochar Sequestration. Environ. Sci. Technol. 49, 14688-14695. 
doi:10.1021/acs.est.5b03548

Davis, S.C., Diegel, S.W., Boundy, R.G., 2014. Transportation Energy data book, 33rd ed. U.S. Department of Energy, Oak Ridge, Tennessee.

Dong, X., Ma, L.Q., Li, Y., 2011. Characteristics and mechanisms of hexavalent chromium removal by biochar from sugar beet tailing. J. Hazard. Mater. 190, 909-915. doi:http://dx.doi.org/10.1016/j.jhazmat.2011.04.008

Downie, A., 2011. Biochar production and use: environmental risks and rewards. the university of south wales.

El-Ashtoukhy, E.-S.Z., Amin, N.K., Abdelwahab, O., 2008. Removal of lead (II) and copper (II) from aqueous solution using pomegranate peel as a new adsorbent. Desalination 223, 162-173. doi:10.1016/j.desal.2007.01.206

Gabarrell, X., Font, M., Vicent, T., Caminal, G., Sarrà, M., Blánquez, P., 2012. A comparative life cycle assessment of two treatment technologies for the Grey Lanaset $\mathrm{G}$ textile dye: biodegradation by Trametes versicolor and granular activated carbon adsorption. Int. J. Life Cycle Assess. 17, 613-624. doi:10.1007/s11367-012-0385-z

Garcia-Nunez, J.A., Ramirez-Contreras, N.E., Rodriguez, D.T., Silva-Lora, E., Frear, C.S., Stockle, C., GarciaPerez, M., 2016. Evolution of palm oil mills into bio-refineries: Literature review on current and potential uses of residual biomass and effluents. Resour. Conserv. Recycl. 110, 99-114. doi:10.1016/j.resconrec.2016.03.022

Gaunt, J.L., Lehmann, J., 2008. Energy balance and emissions associated with biochar sequestration and pyrolysis bioenergy production. Environ. Sci. Technol. 42, 4152-4158. doi:10.1021/es071361i

Google Maps, 2015. Google Maps [WWW Document].

Grassi, M., Kaykioglu, G., Belgiorno, V., 2012. Removal of Emerging Contaminants from Water and Wastewater by Adsorption Process, in: Lofrano, G. (Ed.), Emerging Compounds Removal from Wastewater. pp. 15-38. doi:10.1007/978-94-007-3916-1

Hammond, J., Shackley, S., Sohi, S., Brownsort, P., 2011. Prospective life cycle carbon abatement for pyrolysis biochar systems in the UK. Energy Policy 39, 2646-2655. doi:10.1016/j.enpol.2011.02.033

Han, Y., Boateng, A. a., Qi, P.X., Lima, I.M., Chang, J., 2013. Heavy metal and phenol adsorptive properties of biochars from pyrolyzed switchgrass and woody biomass in correlation with surface properties. J. Environ. Manage. 118, 196-204. doi:10.1016/j.jenvman.2013.01.001

Harsono, S.S., Grundman, P., Lau, L.H., Hansen, A., Salleh, M.A.M., Meyer-Aurich, A., Idris, A., Ghazi, T.I.M., 2013. Energy balances, greenhouse gas emissions and economics of biochar production from palm oil empty fruit bunches. Resour. Conserv. Recycl. 77, 108-115. doi:10.1016/j.resconrec.2013.04.005

Harvey, O.R., Herbert, B.E., Rhue, R.D., Kuo, L.J., 2011. Metal interactions at the biochar-water interface: Energetics and structure-sorption relationships elucidated by flow adsorption microcalorimetry. Environ. Sci. Technol. 45, 5550-5556. doi:10.1021/es104401h

Helleur, R., Popovic, N., Ikura, M., Stanciulescu, M., Liu, D., 2001. Characterization and potential applications of pyrolytic char from ablative pyrolysis of used tires. J. Anal. Appl. Pyrolysis 58-59, 813-824. doi:10.1016/S0165-2370(00)00207-2

Hjaila, K., Baccar, R., Sarrà, M., Gasol, C.M., Blánquez, P., 2013. Environmental impact associated with activated carbon preparation from olive-waste cake via life cycle assessment. J. Environ. Manage. 130, 242-247. doi:10.1016/j.jenvman.2013.08.061

Ibarrola, R., Shackley, S., Hammond, J., 2011. Pyrolysis biochar systems for recovering biodegradable materials: A life cycle carbon assessment. Waste Manag. 32, 859-868. doi:10.1016/j.wasman.2011.10.005

IBI, 2014. State of the Biochar Industry 2014.

Inyang, M., Gao, B., Ding, W., Pullammanappallil, P., Zimmerman, A.R., Cao, X., 2011. Enhanced Lead Sorption by Biochar Derived from Anaerobically Digested Sugarcane Bagasse. Sep. Sci. Technol. 46, 1950-1956.

doi:10.1080/01496395.2011.584604 
Inyang, M., Gao, B., Yao, Y., Xue, Y., Zimmerman, A.R., Pullammanappallil, P., Cao, X., 2012. Removal of heavy metals from aqueous solution by biochars derived from anaerobically digested biomass. Bioresour. Technol. 110, 50-56. doi:10.1016/j.biortech.2012.01.072

Issabayeva, G., Aroua, M.K., Sulaiman, N.M.N., 2006. Removal of lead from aqueous solutions on palm shell activated carbon. Bioresour. Technol. 97, 2350-2355. doi:http://dx.doi.org/10.1016/j.biortech.2005.10.023

Jiang, T.Y., Jiang, J., Xu, R.K., Li, Z., 2012. Adsorption of Pb(II) on variable charge soils amended with rice-straw derived biochar. Chemosphere 89, 249-256. doi:10.1016/j.chemosphere.2012.04.028

Johnsen, D.L., Emamipour, H., Guest, J.S., Rood, M.J., 2016. Environmental and Economic Assessment of Electrothermal Swing Adsorption of Air Emissions from Sheet-Foam Production Compared to Conventional Abatement Techniques. Environ. Sci. Technol. 50, 1465-1472. doi:10.1021/acs.est.5b05004

Karim, A.A., Kumar, M., Mohapatra, S., Panda, C.R., Singh, A., 2015. Banana Peduncle Biochar : Characteristics and Adsorption of Hexavalent Chromium from Aqueous Solution 7, 1-10. doi:10.9734/IRJPAC/2015/16163

Kılıç, M., Kırbıyık, Ç., Çepelioğullar, Ö., Pütün, A.E., 2013. Adsorption of heavy metal ions from aqueous solutions by bio-char, a by-product of pyrolysis. Appl. Surf. Sci. 283, 856-862. doi:10.1016/j.apsusc.2013.07.033

Kobya, M., Demirbas, E., Senturk, E., Ince, M., 2005. Adsorption of heavy metal ions from aqueous solutions by activated carbon prepared from apricot stone. Bioresour. Technol. 96, 1518-1521. doi:http://dx.doi.org/10.1016/j.biortech.2004.12.005

Kołodyńska, D., Wnetrzak, R., Leahy, J.J., Hayes, M.H.B., Kwapiński, W., Hubicki, Z., 2012. Kinetic and adsorptive characterization of biochar in metal ions removal. Chem. Eng. J. 197, 295-305. doi:10.1016/j.cej.2012.05.025

Kuo, L.J., Herbert, B.E., Louchouarn, P., 2008. Can levoglucosan be used to characterize and quantify char/charcoal black carbon in environmental media? Org. Geochem. 39, 1466-1478. doi:10.1016/j.orggeochem.2008.04.026

Li, M., Liu, Q., Guo, L., Zhang, Y., Lou, Z., Wang, Y., Qian, G., 2013. Cu(II) removal from aqueous solution by Spartina alterniflora derived biochar. Bioresour. Technol. 141, 83-88. doi:10.1016/j.biortech.2012.12.096

Libra, J. a, Ro, K.S., Kammann, C., Funke, A., Berge, N.D., Neubauer, Y., Titirici, M.-M., Fühner, C., Bens, O., Kern, J., Emmerich, K.-H., 2011. Hydrothermal carbonization of biomass residuals: a comparative review of the chemistry, processes and applications of wet and dry pyrolysis. Biofuels 2, 71-106. doi:10.4155/bfs.10.81

Liu, Y., Zhao, X., Li, J., Ma, D., Han, R., 2012. Characterization of bio-char from pyrolysis of wheat straw and its evaluation on methylene blue adsorption. Desalin. Water Treat. 46, 115-123. doi:10.1080/19443994.2012.677408

Liu, Z., Zhang, F.S., 2009. Removal of lead from water using biochars prepared from hydrothermal liquefaction of biomass. J. Hazard. Mater. 167, 933-939. doi:10.1016/j.jhazmat.2009.01.085

Mahimairaja, S. and S.S., 2012. Production and characterization of biochar from different biological wastes. Int. J. Plant.Animal Environ. Sci. 2, 197-201.

Medic, D., 2012. Investigation of torrefaction process parameters andcharacterization of torrefied biomass. Iowa State University.

Meyer, S., Bright, R.M., Fischer, D., Schulz, H., Glaser, B., 2012. Albedo impact on the suitability of biochar systems to mitigate global warming. Environ. Sci. Technol. 46, 12726-12734. doi:10.1021/es302302g

Meyer, S., Glaser, B., Quicker, P., 2011. Technical, Economical, and Climate-Related Aspects of Biochar Production Technologies: A Literature Review. Environ. Sci. Technol. 45, 9473-9483. doi:10.1021/es201792c

Mohan, D., Pittman Jr., C.U., Bricka, M., Smith, F., Yancey, B., Mohammad, J., Steele, P.H., Alexandre-Franco, M.F., Gómez-Serrano, V., Gong, H., 2007. Sorption of arsenic, cadmium, and lead by chars produced from fast pyrolysis of wood and bark during bio-oil production. J. Colloid Interface Sci. 310, 57-73. doi:http://dx.doi.org/10.1016/j.jcis.2007.01.020 
Mohan, D., Rajput, S., Singh, V.K., Steele, P.H., Pittman, C.U., 2011. Modeling and evaluation of chromium remediation from water using low cost bio-char, a green adsorbent. J. Hazard. Mater. 188, 319-333. doi:10.1016/j.jhazmat.2011.01.127

Momčilović, M., Purenović, M., Bojić, A., Zarubica, A., Ranđelović, M., 2011. Removal of lead(II) ions from aqueous solutions by adsorption onto pine cone activated carbon. Desalination 276, 53-59. doi:http://dx.doi.org/10.1016/j.desal.2011.03.013

Muñoz, I., Peral, J., Antonio Ayllón, J., Malato, S., José Martin, M., Yves Perrot, J., Vincent, M., Domènech, X., 2007. Life-Cycle Assessment of a Coupled Advanced Oxidation-Biological Process for Wastewater Treatment: Comparison with Granular Activated Carbon Adsorption. Environ. Eng. Sci. 24, 638-651. doi:10.1089/ees.2006.0134

Nhuchhen, D., Basu, P., Acharya, B., 2014. A Comprehensive Review on Biomass Torrefaction. Int. J. Renew. Energy Biofuels 2014, 1-56. doi:10.5171/2014.506376

Oleszczuk, P., Hale, S.E., Lehmann, J., Cornelissen, G., 2012. Activated carbon and biochar amendments decrease pore-water concentrations of polycyclic aromatic hydrocarbons (PAHs) in sewage sludge. Bioresour. Technol. 111, 84-91. doi:10.1016/j.biortech.2012.02.030

Palisade, 2013. @RISK: Risk analysis and simulation add-in for Microsoft ${ }^{\circledR}$ Excel.

Park, J.H., Choppala, G.K., Bolan, N.S., Chung, J.W., Chuasavathi, T., 2011. Biochar reduces the bioavailability and phytotoxicity of heavy metals. Plant Soil 348, 439-451. doi:10.1007/s11104-011-0948-y

Pellera, F.M., Giannis, A., Kalderis, D., Anastasiadou, K., Stegmann, R., Wang, J.Y., Gidarakos, E., 2012. Adsorption of $\mathrm{Cu}(\mathrm{II})$ ions from aqueous solutions on biochars prepared from agricultural by-products. J. Environ. Manage. 96, 35-42. doi:10.1016/j.jenvman.2011.10.010

Pérez-Marín, A.B., Zapata, V.M., Ortuño, J.F., Aguilar, M., Sáez, J., Lloréns, M., 2007. Removal of cadmium from aqueous solutions by adsorption onto orange waste. J. Hazard. Mater. 139, 122-131. doi:http://dx.doi.org/10.1016/j.jhazmat.2006.06.008

Peters, J., Iribarren, D., Dufour, J., 2015. Biomass pyrolysis for biochar or energy applications? A life cycle assessment. Environ. Sci. Technol. 150401141039001. doi:10.1021/es5060786

Rasmussen, E., 2014. International Biochar Initiative [WWW Document]. Http://Www.Biochar-International.Org/.

Rasmussen, E., 2011. Buy Biochar: Manufactured Biochar and Biochar Products [WWW Document]. TR Miles Tech. Consult. Inc.

Regmi, P., Garcia Moscoso, J.L., Kumar, S., Cao, X., Mao, J., Schafran, G., 2012. Removal of copper and cadmium from aqueous solution using switchgrass biochar produced via hydrothermal carbonization process. J. Environ. Manage. 109, 61-69. doi:10.1016/j.jenvman.2012.04.047

Ro, K.S., Cantrell, K.B., Hunt, P.G., 2010. High-temperature pyrolysis of blended animal manures for producing renewable energy and value-added biochar. Ind. Eng. Chem. Res. 49, 10125-10131. doi:10.1021/ie101155m

Roberts, K.G., Gloy, B. a., Joseph, S., Scott, N.R., Lehmann, J., 2010. Life cycle assessment of biochar systems: Estimating the energetic, economic, and climate change potential. Environ. Sci. Technol. 44, 827-833. doi:10.1021/es902266r

Searates, 2015. Transit Time, Distance calculator \& Port to port distances.

Selvi, K., Pattabhi, S., Kadirvelu, K., 2001. Removal of Cr(VI) from aqueous solution by adsorption onto activated carbon. Bioresour. Technol. 80, 87-89. doi:10.1016/S0960-8524(01)00068-2

Shackley, S., Sohi, S., Brownsort, P., Carter, S., 2010. An assessment of the benefits and issues associated with the application of biochar to soil — a report commissioned by the United Kingdom Department for, United Kingdom Department for Environment, Food and Rural Affairs, and Department of Energy and Climate Change. UK, Edinburgh.

Slaughter, M., 2011. Oklahoma city water utilities trust agenda Item No.3.C.2 9/27/2011. 
Sohi, S., Lopez-capel, E., Krull, E., Bol, R., 2009. Biochar , climate change and soil : A review to guide future research. Civ. Eng. 6618, 64. doi:10.1139/Z03-132

Sohi, S.P., Krull, E., Lopez-Capel, E., Bol, R., 2010. Chapter 2 - A Review of Biochar and Its Use and Function in Soil, in: Agronomy, B.T.-A. in (Ed.), Advances in Agronomy. Academic Press, pp. 47-82. doi:http://dx.doi.org/10.1016/S0065-2113(10)05002-9

Song, C., Wu, S., Cheng, M., Tao, P., Shao, M., Gao, G., 2014. Adsorption studies of coconut shell carbons prepared by $\mathrm{KOH}$ activation for removal of lead(ii) from aqueous solutions. Sustain. 6, 86-98. doi:10.3390/su6010086

Sparrevik, M., Field, J.L., Martinsen, V., Breedveld, G.D., Cornelissen, G., 2013. Life cycle assessment to evaluate the environmental impact of biochar implementation in conservation agriculture in Zambia. Environ. Sci. Technol. 47, 1206-1215. doi:10.1021/es302720k

Suguihiro, T.M., de Oliveira, P.R., de Rezende, E.I.P., Mangrich, A.S., Marcolino Junior, L.H., Bergamini, M.F., 2013. An electroanalytical approach for evaluation of biochar adsorption characteristics and its application for Lead and Cadmium determination. Bioresour. Technol. 143, 40-45. doi:10.1016/j.biortech.2013.05.107

Sun, K., Keiluweit, M., Kleber, M., Pan, Z., Xing, B., 2011. Sorption of fluorinated herbicides to plant biomassderived biochars as a function of molecular structure. Bioresour. Technol. 102, 9897-9903. doi:10.1016/j.biortech.2011.08.036

Tong, X.J., Li, J.Y., Yuan, J.H., Xu, R.K., 2011. Adsorption of Cu(II) by biochars generated from three crop straws. Chem. Eng. J. 172, 828-834. doi:10.1016/j.cej.2011.06.069

U.S Department of Energy, 2014. Alternative Fuels Data Center - Fuel Properties Comparison, Energy Efficiency \& Renewable Energy.

US-EPA, 2014. Emission Factors for Greenhouse Gas Inventories.

Woolf, D., Amonette, J.E., Street-Perrott, F.A., Lehmann, J., Joseph, S., 2010a. Sustainable biochar to mitigate global climate change. Nat. Commun. 1, 56. doi:10.1038/ncomms 1053

Woolf, D., Amonette, J.E., Street-Perrott, F.A., Lehmann, J., Joseph, S., 2010b. Sustainable biochar to mitigate global climate change. Nat. Commun. 1, 56. doi:10.1038/ncomms 1053

Xu, R.K., Xiao, S.C., Yuan, J.H., Zhao, A.Z., 2011. Adsorption of methyl violet from aqueous solutions by the biochars derived from crop residues. Bioresour. Technol. 102, 10293-10298. doi:10.1016/j.biortech.2011.08.089

Xu, X., Cao, X., Zhao, L., Wang, H., Yu, H., Gao, B., 2013. Removal of Cu, Zn, and Cd from aqueous solutions by the dairy manure-derived biochar. Environ. Sci. Pollut. Res. 20, 358-368. doi:10.1007/s11356-012-0873-5

Yan, W., Acharjee, T.C., Coronella, C.J., Vásquez, V.R., 2009. Thermal pretreatment of lignocellulosic biomass. Environ. Prog. Sustain. Energy 28, 435-440. doi:10.1002/ep.10385

Yao, Y., Gao, B., Chen, H., Jiang, L., Inyang, M., Zimmerman, A.R., Cao, X., Yang, L., Xue, Y., Li, H., 2012. Adsorption of sulfamethoxazole on biochar and its impact on reclaimed water irrigation. J. Hazard. Mater. 209-210, 408-413. doi:10.1016/j.jhazmat.2012.01.046

Yao, Y., Gao, B., Inyang, M., Zimmerman, A.R., Cao, X., Pullammanappallil, P., Yang, L., 2011a. Biochar derived from anaerobically digested sugar beet tailings: Characterization and phosphate removal potential. Bioresour. Technol. 102, 6273-6278. doi:10.1016/j.biortech.2011.03.006

Yao, Y., Gao, B., Inyang, M., Zimmerman, A.R., Cao, X., Pullammanappallil, P., Yang, L., 2011b. Removal of phosphate from aqueous solution by biochar derived from anaerobically digested sugar beet tailings. J. Hazard. Mater. 190, 501-507. doi:10.1016/j.jhazmat.2011.03.083

Zhang, P., Sun, H., Yu, L., Sun, T., 2013. Adsorption and catalytic hydrolysis of carbaryl and atrazine on pig manure-derived biochars: impact of structural properties of biochars. J. Hazard. Mater. 244-245, 217-24. doi:10.1016/j.jhazmat.2012.11.046 
Zhang, X., Wang, H., He, L., Lu, K., Sarmah, A., Li, J., Bolan, N.S., Pei, J., Huang, H., 2013. Using biochar for remediation of soils contaminated with heavy metals and organic pollutants. Environ. Sci. Pollut. Res. 20, 8472-8483. doi:10.1007/s11356-013-1659-0

Zheng, W., Li, X., Wang, F., Yang, Q., Deng, P., Zeng, G., 2008. Adsorption removal of cadmium and copper from aqueous solution by areca-A food waste. J. Hazard. Mater. 157, 490-495. doi:http://dx.doi.org/10.1016/j.jhazmat.2008.01.029 


\section{Appendix A}

Table A1. Adsorption capacity of biochar and activated carbon produced from different raw materials. Products have been grouped based on adsorbed materials to ease comparison of adsorption capacity.

\begin{tabular}{|c|c|c|c|c|c|c|c|c|c|}
\hline Adsorbent & $\begin{array}{c}\text { Particle } \\
\text { size of } \\
\text { adsorbent } \\
\text {, mm } \\
\end{array}$ & $\begin{array}{c}\text { Surface } \\
\text { area, } \\
\mathrm{m}^{2} / \mathrm{g}\end{array}$ & pH & $\begin{array}{c}\text { Contaminants } \\
\text { concentration } \\
, \mathrm{mg} / \mathrm{l}\end{array}$ & $\begin{array}{c}\text { Adsorbent } \\
\text { dose, } \\
\text { g/l }\end{array}$ & $\begin{array}{l}\text { Contact } \\
\text { time, } \\
\text { hour }\end{array}$ & $\begin{array}{c}\text { Adsorbed } \\
\text { material }\end{array}$ & $\begin{array}{l}\text { Adsorption } \\
\text { capacity, } \\
\text { mg/g }\end{array}$ & References \\
\hline $\begin{array}{l}\text { Switchgrass via hydrothermal } \\
\text { carbonization biochar }\end{array}$ & $>0.045$ & 2.11 & 5 & 40 & 2 & 24 & $\mathrm{Cd}$ & 1.5 & \multirow[t]{3}{*}{ (Regmi et al., 2012) } \\
\hline Activated biochar & $>0.045$ & 5.01 & 5 & 40 & 2 & 24 & $\mathrm{Cd}$ & 34 & \\
\hline Powdered activated carbon & $\begin{array}{l}0.044- \\
0.149 \\
\end{array}$ & 726 & 5 & 40 & 2 & 24 & $\mathrm{Cd}$ & 1.5 & \\
\hline Dairy manure-derived biochar & 0.5 & 5.61 & & 562 & & 10 & $\mathrm{Cd}$ & 51.4 & \multirow{4}{*}{$\begin{array}{c}\text { (Mohan et al., 2007; X. Xu } \\
\text { et al., 2013) }\end{array}$} \\
\hline Oak bark biochar & $0.25-0.6$ & 25.4 & 8.2 & 0.125 & & 24 & $\mathrm{Cd}$ & 5.4 & \\
\hline Pine bark biochar & $0.25-0.6$ & 1.88 & 8.2 & 0.125 & & 24 & $\mathrm{Cd}$ & 0.34 & \\
\hline Granular activated carbon & $0.25-0.6$ & 984 & 8.2 & 0.125 & & 24 & $\mathrm{Cd}$ & 8 & \\
\hline Cord grass biochar & $<0.25$ & 15.1 & 5 & & & & $\mathrm{Cd}$ & $5.7-42.5$ & \multirow{3}{*}{$\begin{array}{c}\text { (Harvey et al., 2011; Kuo et } \\
\text { al., 2008) }\end{array}$} \\
\hline Loblolly pine biochar & $<0.25$ & 281 & 5 & & & & $\mathrm{Cd}$ & $2.92-6.97$ & \\
\hline Honey mesquite biochar & $<0.25$ & 107 & 5 & & & & $\mathrm{Cd}$ & $5.5-18$ & \\
\hline Peanut straw biochar & 0.048 & & 5 & $157-790$ & 2 & & $\mathrm{Cu}$ & 89 & \multirow[t]{4}{*}{ (Tong et al., 2011) } \\
\hline Soybean straw biochar & 0.048 & & 5 & $157-790$ & 2 & & $\mathrm{Cu}$ & 52.7 & \\
\hline Canola straw biochar & 0.048 & & 5 & $157-790$ & 2 & & $\mathrm{Cu}$ & 37.5 & \\
\hline Activated carbon & 0.048 & & 5 & $157-790$ & 2 & & $\mathrm{Cu}$ & 11.4 & \\
\hline Rice husks hydrothermal biochar & $<0.5$ & & $5-6$ & & $5-12.5$ & $2-4$ & $\mathrm{Cu}$ & 1.09 & \multirow[t]{8}{*}{ (Pellera et al., 2012) } \\
\hline Rice husks biochar (pyrolysis) & $<0.5$ & & $5-6$ & $20-50$ & $5-12.5$ & $2-4$ & $\mathrm{Cu}$ & $0.02-2.9$ & \\
\hline Olive pomace biochar (hydrothermal) & $<0.5$ & & $5-6$ & $20-50$ & $5-12.5$ & $2-4$ & $\mathrm{Cu}$ & 0.6 & \\
\hline Olive pomace biochar (pyrolysis) & $<0.5$ & & $5-6$ & $20-50$ & $5-12.5$ & $2-4$ & $\mathrm{Cu}$ & $0.17-1.3$ & \\
\hline Orange waste biochar (hydrothermal) & $<0.5$ & & $5-6$ & $20-50$ & $5-12.5$ & $2-4$ & $\mathrm{Cu}$ & 2.03 & \\
\hline Orange waste biochar (pyrolysis) & $<0.5$ & & $5-6$ & $20-50$ & $5-12.5$ & $2-4$ & $\mathrm{Cu}$ & $0.08-1.4$ & \\
\hline Compost biochar (hydrothermal) & $<0.5$ & & $5-6$ & $20-50$ & $5-12.5$ & $2-4$ & $\mathrm{Cu}$ & 3.8 & \\
\hline Compost biochar (pyrolysis) & $<0.5$ & & $5-6$ & $20-50$ & $5-12.5$ & $2-4$ & $\mathrm{Cu}$ & $2.4-3.6$ & \\
\hline Spartina alterniflor biochar & $<0.3$ & 2.3 & 6 & 290 & 3.3 & & $\mathrm{Cu}$ & 48.5 & (Li et al., 2013) \\
\hline
\end{tabular}




\begin{tabular}{|c|c|c|c|c|c|c|c|c|c|}
\hline Adsorbent & $\begin{array}{c}\text { Particle } \\
\text { size of } \\
\text { adsorbent } \\
\text {, mm }\end{array}$ & $\begin{array}{c}\text { Surface } \\
\text { area, } \\
\mathbf{m}^{2} / \mathrm{g}\end{array}$ & $\mathbf{p H}$ & $\begin{array}{c}\text { Contaminants } \\
\text { concentration } \\
, \mathrm{mg} / \mathrm{l}\end{array}$ & $\begin{array}{c}\text { Adsorbent } \\
\text { dose, } \\
\text { g/l }\end{array}$ & $\begin{array}{l}\text { Contact } \\
\text { time, } \\
\text { hour }\end{array}$ & $\begin{array}{c}\text { Adsorbed } \\
\text { material }\end{array}$ & $\begin{array}{l}\text { Adsorption } \\
\text { capacity, } \\
\text { mg/g }\end{array}$ & References \\
\hline Softwood biochar & $>0.0002$ & 362 & 4.8 & & 10 & 24 & $\mathrm{Cu}$ & $1.6-11$ & \\
\hline Activated carbon & $>0.0002$ & 383 & 4.8 & & 10 & 24 & $\mathrm{Cu}$ & $6.3-30.2$ & \\
\hline Hardwood biochar & $<0.5$ & 0.43 & 7 & 63 & 5 & 24 & $\mathrm{Cu}$ & 6.8 & \multirow[t]{2}{*}{ (X. Chen et al., 2011) } \\
\hline Corn straw biochar & $<0.5$ & 13.98 & 5 & 63 & 5 & 24 & $\mathrm{Cu}$ & 12.5 & \\
\hline $\begin{array}{l}\text { Switchgrass via hydrothermal } \\
\text { carbonization biochar }\end{array}$ & $>0.045$ & 2.11 & 5 & 40 & 2 & 24 & $\mathrm{Cu}$ & 4 & \multirow[t]{3}{*}{ (Regmi et al., 2012) } \\
\hline Activated biochar & $>0.045$ & 5.01 & 5 & 40 & 2 & 24 & $\mathrm{Cu}$ & 31 & \\
\hline Powdered activated carbon & $\begin{array}{l}0.044- \\
0.149\end{array}$ & 726 & 5 & 40 & 2 & 24 & $\mathrm{Cu}$ & 1.8 & \\
\hline Pig manure chemically treated biochar & $0.42-0.6$ & 15 & 5 & $6.3-157$ & 5 & & $\mathrm{Cu}$ & 6.8 & (Kołodyńska et al., 2012) \\
\hline Dairy manure-derived biochar & 0.5 & 5.61 & & 317 & & 10 & $\mathrm{Cu}$ & 54.4 & (Xu et al., 2013) \\
\hline Oak wood biochar & $0.25-0.6$ & 2.73 & 2 & $1-100$ & & & $\mathrm{Cr}$ VI & $3.03-4.9$ & \multirow[t]{7}{*}{ (Mohan et al., 2011) } \\
\hline Oak bark biochar & $0.25-0.6$ & 1.88 & 2 & $1-100$ & & & Cr VI & $4.6-7.5$ & \\
\hline $\begin{array}{l}\text { Activated carbon derived from } \\
\text { coconut fibers }\end{array}$ & & 343 & 2 & $1-100$ & & & $\mathrm{Cr}$ VI & $16-24$ & \\
\hline $\begin{array}{l}\text { Activated carbon derived from } \\
\text { coconut shells }\end{array}$ & & 378 & 2 & $1-100$ & & & Cr VI & $1.4-32.6$ & \\
\hline $\begin{array}{l}\text { Activated carbon derived from acid- } \\
\text { treated coconut fibers }\end{array}$ & & 512 & 2 & $1-100$ & & & $\mathrm{Cr}$ VI & $1.1-15.6$ & \\
\hline $\begin{array}{l}\text { Activated carbon derived from acid- } \\
\text { treated coconut shells }\end{array}$ & & 380 & 2 & $1-100$ & & & Cr VI & $1.6-16.4$ & \\
\hline Activated carbon fabric cloth & & 1565 & 2 & $1-100$ & & & $\mathrm{Cr}$ VI & $42.1-117$ & \\
\hline Commercial activated carbon & $0.5-2.36$ & 1000 & 6 & $5-25$ & & & Cr VI & 4.7 & \multirow{7}{*}{$\begin{array}{l}\text { (Babel and Kurniawan, } \\
\text { 2004; Mohan et al., 2011) }\end{array}$} \\
\hline $\begin{array}{l}\text { Commercial activated carbon oxidized } \\
\text { with sulfuric acid }\end{array}$ & $0.5-2.36$ & 1000 & 6 & $5-25$ & & & Cr VI & 8.9 & \\
\hline $\begin{array}{l}\text { Commercial activated carbon oxidized } \\
\text { with nitric acid }\end{array}$ & $0.5-2.36$ & 1000 & 6 & $5-25$ & & & Cr VI & 10.4 & \\
\hline Coconut shell activated carbon & $0.42-1.70$ & $5-10$ & 6 & $5-25$ & & & $\mathrm{Cr}$ VI & 2.2 & \\
\hline $\begin{array}{l}\text { Coconut shell charcoal coated with } \\
\text { chitosan activated carbon }\end{array}$ & $0.42-1.70$ & $5-10$ & 6 & $5-25$ & & & $\mathrm{Cr}$ VI & 3.7 & \\
\hline $\begin{array}{l}\text { Coconut shell charcoal Oxidized with } \\
\text { sulfuric acid activated carbon }\end{array}$ & $0.42-1.70$ & $5-10$ & 6 & $5-25$ & & & $\mathrm{Cr}$ VI & 4.1 & \\
\hline $\begin{array}{l}\text { Coconut shell charcoal oxidized with } \\
\text { sulfuric acid and coated with chitosan }\end{array}$ & $0.42-1.70$ & $5-10$ & 6 & $5-25$ & & & Cr VI & 9 & \\
\hline
\end{tabular}




\begin{tabular}{|c|c|c|c|c|c|c|c|c|c|}
\hline Adsorbent & $\begin{array}{c}\text { Particle } \\
\text { size of } \\
\text { adsorbent } \\
\text {, mm }\end{array}$ & $\begin{array}{c}\text { Surface } \\
\text { area, } \\
\mathrm{m}^{2} / \mathrm{g}\end{array}$ & $\mathbf{p H}$ & $\begin{array}{c}\text { Contaminants } \\
\text { concentration } \\
\text {, mg/l }\end{array}$ & $\begin{array}{l}\text { Adsorbent } \\
\text { dose, } \\
\text { g/l }\end{array}$ & $\begin{array}{l}\text { Contact } \\
\text { time, } \\
\text { hour }\end{array}$ & $\begin{array}{c}\text { Adsorbed } \\
\text { material }\end{array}$ & $\begin{array}{c}\text { Adsorption } \\
\text { capacity, } \\
\text { mg/g }\end{array}$ & References \\
\hline $\begin{array}{l}\text { Coconut shell charcoal oxidized with } \\
\text { nitric acid activated carbon }\end{array}$ & $0.42-1.70$ & $5-10$ & 6 & $5-25$ & & & Cr VI & 11 & \\
\hline $\begin{array}{l}\text { Commercial activated carbon type } \\
\text { Filtrasorb- } 400\end{array}$ & & 1000 & 2 & 100 & & & Cr VI & 53.2 & \multirow[t]{3}{*}{$\begin{array}{l}\text { (Babel and Kurniawan, } \\
\text { 2004) }\end{array}$} \\
\hline Waste tire activated carbon & & & 2 & 100 & & & Cr VI & 58.5 & \\
\hline Rice husk activated carbon & & & $2-3$ & 300 & & & Cr VI & 45.6 & \\
\hline Coconut tree sawdust activated carbon & $\begin{array}{l}0.125- \\
0.250\end{array}$ & $5-10$ & 3 & 20 & & & Cr VI & 3.5 & $\begin{array}{l}\text { (Babel and Kurniawan, } \\
\text { 2004; Selvi et al., 2001) }\end{array}$ \\
\hline Sugar beet tailing biochar & & & & & & & Cr VI & 123 & $\begin{array}{c}\text { (Dong et al., 2011; } \\
\text { Suguihiro et al., 2013) }\end{array}$ \\
\hline Banana Peduncle Biochar & $\leq 0.1$ & & 2 & & 2 & 24 & Cr VI & 114 & (Karim et al., 2015) \\
\hline $\begin{array}{l}\text { Anaerobically digested sugarcane } \\
\text { bagasse biochar }\end{array}$ & $0.5-1$ & 17.7 & & 20 & 1.6 & 24 & $\mathrm{~Pb}$ & 136 & \multirow[t]{3}{*}{ (Inyang et al., 2011) } \\
\hline Granular activated carbon & $0.5-1$ & 1100 & & 20 & 1.6 & 24 & $\mathrm{~Pb}$ & 81.9 & \\
\hline Sugarcane bagasse biochar & $0.5-1$ & 14.1 & & 20 & 1.6 & 24 & $\mathrm{~Pb}$ & 6.5 & \\
\hline Pinewood biochar & $<0.5$ & & 5 & 20 & 4 & 24 & $\mathrm{~Pb}$ & 4.25 & \multirow[t]{2}{*}{ (Liu and Zhang, 2009) } \\
\hline Rice husk biochar & $<0.5$ & & 5 & 20 & 4 & 24 & $\mathrm{~Pb}$ & 2.4 & \\
\hline Digested dairy waste biochar & $0.5-1$ & 555.2 & 5 & 20 & 2 & 24 & $\mathrm{~Pb}$ & 33.5 & \multirow[t]{2}{*}{ (Inyang et al., 2012) } \\
\hline Digested whole sugar beet biochar & $0.5-1$ & 128.5 & 5 & 20 & 2 & 24 & $\mathrm{~Pb}$ & 18 & \\
\hline Coconut shell activated carbon & $1-2$ & 728 & 5 & & 4 & & $\mathrm{~Pb}$ & 112 & \multirow{5}{*}{$\begin{array}{l}\text { (Issabayeva et al., 2006; } \\
\text { Kobya et al., 2005; } \\
\text { Momčilović et al., 2011; } \\
\text { Song et al., 2014) }\end{array}$} \\
\hline $\begin{array}{l}\text { Coconut shell carbon (CSC-B) 2:1 } \\
(\mathrm{KOH} / \mathrm{CSC}) \mathrm{AC}\end{array}$ & $1-2$ & 1135 & 5 & & 4 & & $\mathrm{~Pb}$ & 152 & \\
\hline Pine cone activated carbon & & 1094 & 5 & & 2 & & $\mathrm{~Pb}$ & 27.5 & \\
\hline Palm shell activated carbon & & 957 & 5 & & 5 & & $\mathrm{~Pb}$ & 95.2 & \\
\hline Apricot stone activated carbon & & 566 & 5 & & 2 & & $\mathrm{~Pb}$ & 22.8 & \\
\hline Pig manure chemically treated biochar & $0.42-0.6$ & 15 & 5 & $20-517$ & 5 & & $\mathrm{~Pb}$ & 21.4 & (Kołodyńska et al., 2012) \\
\hline Rice straw biochar & 0.25 & 26.45 & 5 & & & & $\mathrm{~Pb}$ & $8.3-8.7$ & (Jiang et al., 2012) \\
\hline Dairy manure biochar & & 6.4 & & 207 & 5 & 4 & $\mathrm{~Pb}$ & 41 & \multirow[t]{2}{*}{ (Cao et al., 2009) } \\
\hline Commercial activated carbon & 0.15 & 421 & & 207 & 5 & 4 & $\mathrm{~Pb}$ & 7 & \\
\hline Switchgrass biochar & $>0.0002$ & 3.6 & 4.8 & & 10 & 24 & $\mathrm{Zn}$ & $0.33-9.6$ & \multirow[t]{4}{*}{ (Han et al., 2013) } \\
\hline Hardwood biochar & $>0.0002$ & 372.75 & 4.8 & & 10 & 24 & $\mathrm{Zn}$ & $0.07-188$ & \\
\hline Softwood biochar & $>0.0002$ & 362.33 & 4.8 & & 10 & 24 & $\mathrm{Zn}$ & $0.45-256$ & \\
\hline Activated carbon & $>0.0002$ & 167.8 & 4.8 & & 10 & 24 & $\mathrm{Zn}$ & $0.20-9$ & \\
\hline Pig manure chemically treated biochar & $0.42-0.6$ & 15 & 5 & $6.5-163$ & 5 & & $\mathrm{Zn}$ & 6.5 & (Kołodyńska et al., 2012) \\
\hline
\end{tabular}




\begin{tabular}{|c|c|c|c|c|c|c|c|c|c|}
\hline Adsorbent & $\begin{array}{c}\text { Particle } \\
\text { size of } \\
\text { adsorbent } \\
\text {, mm }\end{array}$ & $\begin{array}{c}\text { Surface } \\
\text { area, } \\
\mathrm{m}^{2} / \mathrm{g}\end{array}$ & pH & $\begin{array}{c}\text { Contaminants } \\
\text { concentration } \\
\quad, \mathrm{mg} / \mathrm{l}\end{array}$ & $\begin{array}{c}\text { Adsorbent } \\
\text { dose, } \\
\text { g/l }\end{array}$ & $\begin{array}{l}\text { Contact } \\
\text { time, } \\
\text { hour }\end{array}$ & $\begin{array}{c}\text { Adsorbed } \\
\text { material }\end{array}$ & $\begin{array}{l}\text { Adsorption } \\
\text { capacity, } \\
\text { mg/g }\end{array}$ & References \\
\hline Dairy manure-derived biochar & 0.5 & 5.61 & & 327 & & 10 & $\mathrm{Zn}$ & 32.8 & (Xu et al., 2013) \\
\hline Hardwood biochar & $<0.5$ & 0.43 & 7.5 & 65 & 5 & 24 & $\mathrm{Zn}$ & 4.5 & \multirow[t]{2}{*}{ (X. Chen et al., 2011) } \\
\hline Corn straw biochar & $<0.5$ & 13.98 & 8 & 65 & 5 & 24 & $\mathrm{Zn}$ & 11 & \\
\hline
\end{tabular}




\section{Appendix B}

Table B1. Distance $(\mathrm{km})$ between U.S. states and country capitals that were included in this study (Google Maps, 2015; Searates, 2015)

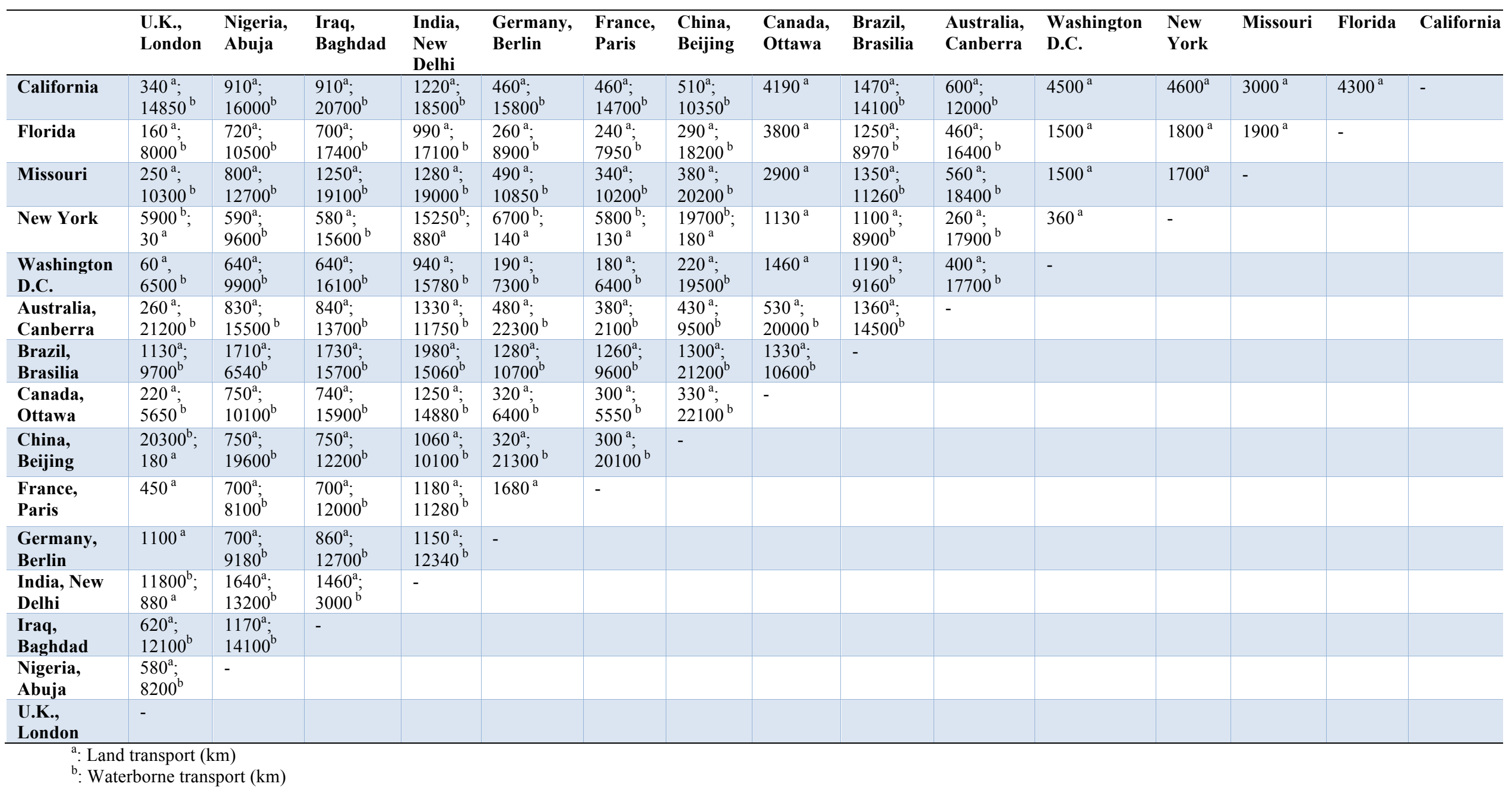


Table B2. Energy consumed to transport biochar between U.S. states and country capitals that were included in this study (MJ/ton biochar)

\begin{tabular}{|c|c|c|c|c|c|c|c|c|c|c|c|c|c|c|c|}
\hline & $\begin{array}{l}\text { U.K., } \\
\text { London }\end{array}$ & $\begin{array}{l}\text { Nigeria, } \\
\text { Abuja }\end{array}$ & $\begin{array}{l}\text { Iraq, } \\
\text { Baghdad }\end{array}$ & $\begin{array}{l}\text { India, } \\
\text { New } \\
\text { Delhi }\end{array}$ & $\begin{array}{l}\text { Germany, } \\
\text { Berlin }\end{array}$ & $\begin{array}{l}\text { France, } \\
\text { Paris }\end{array}$ & $\begin{array}{l}\text { China, } \\
\text { Beijing }\end{array}$ & $\begin{array}{l}\text { Canada, } \\
\text { Ottawa }\end{array}$ & $\begin{array}{l}\text { Brazil, } \\
\text { Brasilia }\end{array}$ & $\begin{array}{l}\text { Australia, } \\
\text { Canberra }\end{array}$ & $\begin{array}{l}\text { Washington } \\
\text { D.C. }\end{array}$ & $\begin{array}{l}\text { New } \\
\text { York }\end{array}$ & Missouri & Florida & California \\
\hline California & 2240 & 2710 & 3370 & 3230 & 2450 & 2290 & 1710 & 2310 & 2760 & 1990 & 2460 & 2550 & 1640 & 2380 & - \\
\hline Florida & 1200 & 1850 & 2800 & 2910 & 1370 & 1230 & 2680 & 2100 & 1930 & 2530 & 810 & 1010 & 1030 & - & \\
\hline Missouri & 1570 & 2200 & 3330 & 3340 & 1770 & 1600 & 3020 & 1610 & 2300 & 2860 & 820 & 940 & - & & \\
\hline New York & 840 & 1660 & 2480 & 2590 & 1010 & 870 & 2820 & 620 & 1860 & 2620 & 198 & - & & & \\
\hline $\begin{array}{l}\text { Washington } \\
\text { D.C. }\end{array}$ & 940 & 1720 & 2590 & 2700 & 1120 & 980 & 2830 & 800 & 1920 & 2670 & - & & & & \\
\hline $\begin{array}{l}\text { Australia, } \\
\text { Canberra }\end{array}$ & 3090 & 2610 & 2370 & 2360 & 3350 & 3130 & 1550 & 3060 & 2760 & - & & & & & \\
\hline $\begin{array}{l}\text { Brazil, } \\
\text { Brasilia }\end{array}$ & 1980 & 1850 & 3120 & 3170 & 2190 & 2020 & 3660 & 1460 & - & & & & & & \\
\hline $\begin{array}{l}\text { Canada, } \\
\text { Ottawa }\end{array}$ & 900 & 1810 & 2610 & 2750 & 1060 & 940 & 3250 & - & & & & & & & \\
\hline $\begin{array}{l}\text { China, } \\
\text { Beijing }\end{array}$ & 2910 & 3130 & 2110 & 1970 & 3120 & 2960 & - & & & & & & & & \\
\hline France, Paris & 250 & 1500 & 2050 & 2220 & 920 & - & & & & & & & & & \\
\hline $\begin{array}{l}\text { Germany, } \\
\text { Berlin }\end{array}$ & 600 & 1660 & 2230 & 2350 & - & & & & & & & & & & \\
\hline $\begin{array}{l}\text { Iraq, } \\
\text { Baghdad }\end{array}$ & 2020 & 2600 & - & & & & & & & & & & & & \\
\hline $\begin{array}{l}\text { Nigeria, } \\
\text { Abuja }\end{array}$ & 1450 & - & & & & & & & & & & & & & \\
\hline U.K., London & - & & & & & & & & & & & & & & \\
\hline
\end{tabular}


Table B3. Greenhouse gas emissions resulting from international trade of biochar between U.S. states and country capitals that were included in this study (kg $\mathrm{CO}_{2}$ eq./ton biochar)

\begin{tabular}{|c|c|c|c|c|c|c|c|c|c|c|c|c|c|c|c|}
\hline & $\begin{array}{l}\text { U.K., } \\
\text { London }\end{array}$ & $\begin{array}{l}\text { Nigeria, } \\
\text { Abuja }\end{array}$ & $\begin{array}{l}\text { Iraq, } \\
\text { Baghdad }\end{array}$ & $\begin{array}{l}\text { India, } \\
\text { New } \\
\text { Delhi }\end{array}$ & $\begin{array}{l}\text { Germany, } \\
\text { Berlin }\end{array}$ & $\begin{array}{l}\text { France, } \\
\text { Paris }\end{array}$ & $\begin{array}{l}\text { China, } \\
\text { Beijing }\end{array}$ & $\begin{array}{l}\text { Canada, } \\
\text { Ottawa }\end{array}$ & $\begin{array}{l}\text { Brazil, } \\
\text { Brasilia }\end{array}$ & $\begin{array}{l}\text { Australia, } \\
\text { Canberra }\end{array}$ & $\begin{array}{l}\text { Washington } \\
\text { D.C. }\end{array}$ & $\begin{array}{l}\text { New } \\
\text { York }\end{array}$ & Missouri & Florida & $\overline{\text { California }}$ \\
\hline California & 450 & 590 & 710 & 710 & 500 & 470 & 370 & 780 & 640 & 420 & 830 & 860 & 550 & 800 & - \\
\hline Florida & 240 & 410 & 590 & 630 & 280 & 250 & 530 & 410 & 470 & 520 & 270 & 340 & 350 & - & \\
\hline Missouri & 320 & 480 & 730 & 740 & 380 & 330 & 600 & 540 & 550 & 590 & 280 & 320 & - & & \\
\hline New York & 160 & 360 & 520 & 540 & 200 & 180 & 550 & 210 & 450 & 520 & 70 & - & & & \\
\hline $\begin{array}{l}\text { Washington } \\
\text { D.C. }\end{array}$ & 180 & 380 & 540 & 590 & 230 & 200 & 550 & 270 & 460 & 540 & - & & & & \\
\hline $\begin{array}{l}\text { Australia, } \\
\text { Canberra }\end{array}$ & 610 & 560 & 520 & 550 & 680 & 620 & 330 & 620 & 630 & - & & & & & \\
\hline $\begin{array}{l}\text { Brazil, } \\
\text { Brasilia }\end{array}$ & 470 & 490 & 730 & 760 & 520 & 490 & 800 & 520 & - & & & & & & \\
\hline $\begin{array}{l}\text { Canada, } \\
\text { Ottawa }\end{array}$ & 190 & 400 & 550 & 620 & 230 & 200 & 640 & - & & & & & & & \\
\hline $\begin{array}{l}\text { China, } \\
\text { Beijing }\end{array}$ & 570 & 650 & 460 & 460 & 620 & 580 & - & & & & & & & & \\
\hline France, Paris & 80 & 340 & 350 & 520 & 310 & - & & & & & & & & & \\
\hline $\begin{array}{l}\text { Germany, } \\
\text { Berlin }\end{array}$ & 200 & 370 & 490 & 540 & - & & & & & & & & & & \\
\hline $\begin{array}{l}\text { Iraq, } \\
\text { Baghdad }\end{array}$ & 430 & 590 & - & & & & & & & & & & & & \\
\hline $\begin{array}{l}\text { Nigeria, } \\
\text { Abuja }\end{array}$ & 320 & - & & & & & & & & & & & & & \\
\hline U.K., London & - & & & & & & & & & & & & & & \\
\hline
\end{tabular}

